Florida International University FIU Digital Commons

\title{
Tittmann and the 'Tiger Car' : competing conceptions of modernity in Haiti, 1946-50
}

Sean Bloch

Florida International University

DOI: $10.25148 /$ etd.FI14051171

Follow this and additional works at: https://digitalcommons.fiu.edu/etd

Part of the Latin American History Commons

\section{Recommended Citation}

Bloch, Sean, "Tittmann and the 'Tiger Car' : competing conceptions of modernity in Haiti, 1946-50" (2003). FIU Electronic Theses and Dissertations. 1713.

https://digitalcommons.fiu.edu/etd/1713 
Miami, Florida

\title{
TITTMANN AND THE 'TIGER CAR:' COMPETEING CONCEPTIONS OF MODERNITY IN HAITI, 1946-50
}

\author{
A thesis submitted in partial fulfillment of the \\ requirements for the degree of \\ MASTER OF ARTS \\ in \\ HISTORY \\ by \\ Sean Bloch
}

2003 
To: Dean Arthur W. Herriott

College of Arts and Sciences

This thesis, written by Sean Bloch, and entitled Tittmann and the 'Tiger Car:'

Competing Conceptions of Modernity in Haiti, 1946-50, having been approved in respect to style and intellectual content, is referred to you for judgment.

We have read this thesis and recommend that it be approved.

Terry Rey

William Walker

James Sweet, Major Professor

Date of Defense: July 26, 2003

The thesis of Sean Bloch is approved.

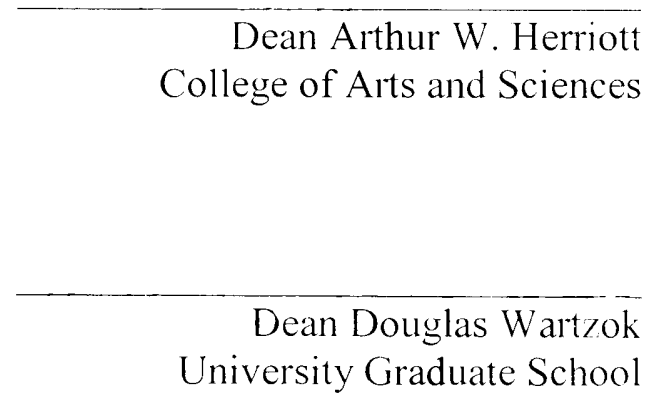

Florida International University, 2003 


\section{ACKNOWLEDGMENTS}

I offer much thanks to all of those who aided me in this project. I am especially grateful to the members of my committee. Terry Rey provided me with a host of important sources and his knowledge of Haiti was invaluable. William Walker did a great deal to help me clarify my thesis and place it in the larger context of foreign relations. Jim Sweet has been a true mentor to me and his guidance has been the central feature of my academic growth, without him I would be lost. All members of my committee approached this project with a positive attitude and were always available to aid and challenge me.

I would also like to single out the Department of History and the Latin American and Caribbean Center for providing the funds essential to the continuance of my academic career and the research my project required. I am thankful to JeanRobert Cadely for teaching me Haitian Creole and introducing me to Haiti itself. I need to express my appreciation to my grandfather and parents for stressing the importance of education and doing what I love. Further thanks are in order to my uncle Daniel for preparing me for graduate school. I thank my sister for imparting her pragmatic brilliance to me whenever possible, her perspective has greatly influenced me. Finally I desire to thank all of my friends for their constant support. I hope I have not waxed too pretentiously eloquent in offering my thanks to everyone who has been absolutely essential to this project and my life in general. 


\section{ABSTRACT OF THE THESIS \\ TITTMANN AND THE 'TIGER CAR:' COMPETING CONCEPTIONS OF MODERNITY IN HAITI, 1946-50}

by

Sean Bloch

Florida International University, 2003

Miami, Florida

Professor James Sweet, Major Professor

The purpose of this project was to address the lack of scholarship on mid-twentieth century Haitian history and illustrate its significance. It employs primary and secondary sources in shaping a Gramscian historical narrative. Ideas of "everyday resistance" and internal and external politics are also be of significance to this work. In mid-twentieth century Haiti, the black-nationalist rhetoric of noirisme became the dominant political ideology. Blackness was amorphous and its application to politics was dependent upon class. In proclaiming blackness the average Haitian was attacking the class schism that beleaguered the island. Yet for the elite noirisme was a conduit to modernity and a useful tool for muting the division between rich and poor. With the election of Dumarsais Estimé in 1946, dialogue between the U.S. government, the Haitian elite, and the masses, relative to definitions of modernity played out within the new political reality of noirisme. 
I. INTRODUCTION ......................................................

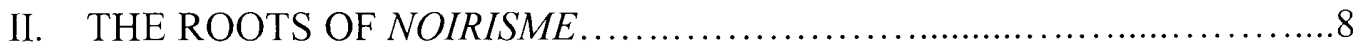

III. THE APPROPRIATION OF BLACKNESS .............................20

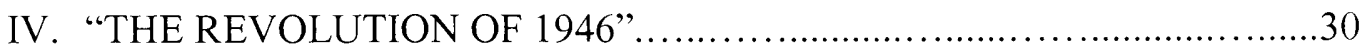

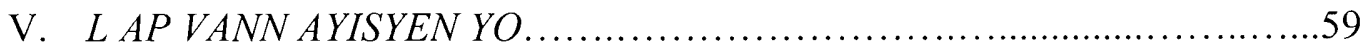

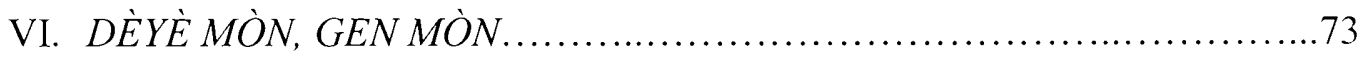

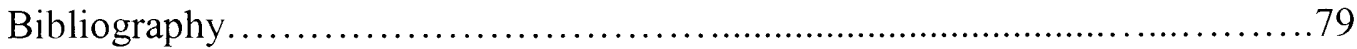




\section{Introduction}

In a 1951 policy statement the United States government noted, "there are racial complications in US-Haitian relations." It is no coincidence that "racial complications" were of primary concern in U.S. relations with the "Negro republic",2 after the overthrow of Haitian President Dumarsais Estimé, for they were central to foreign relations during his tenure. His presidency, 1946-50, was the stage for the victory of noirisme, which consisted in part of the belief that blacks were responsible for the defense of Haitian autonomy. ${ }^{3}$ It was also the setting for reinvigorated governmental resistance to U.S. hegemony after thirty years of post-occupation administrative complaisance. This contestation of hegemony was rooted in a noiriste rhetoric, which depicted the United States as a white oppressor that used money and military force to further its imperial project. Therefore noiristes strove to free Haiti from outside powers and place it under the control of blacks. In 1946 Estimé was elected president of Haiti running on a noiriste platform and became the first black president in decades. ${ }^{4}$ The Estimé presidency was a reminder that the U.S. supported racial schism between "black" and "mulatto" was subject to inversion. Aside from the U.S. occupation, the Estimé presidency was perhaps the most pronounced instance of U.S.-Haitian conflict prior to Papa Doc (I957-71). It was also the period when

\footnotetext{
${ }^{1}$ U.S. Department of State, Foreign Relations of the United States: 195/ (Washington, DC, 1979), p. 1455 [Hereafter FRUS].

2 Ibid.

3 David Nicholls, From Dessalines to Duvalier: Race Colour and National Independence in Haiti (New Brunswick, NJ, 1996), p. 258.

${ }^{4}$ The last black president prior to Estimé was Vilbrun Guillaume Sam.
} 
noirisme confronted the economic disparity of the island and its promises were put to the test.

The hegemonic conflict between the United States, the Haitian government, and the Haitian people is perhaps most apparent in their respective approaches to modernity. From the U.S. perspective, as evidenced by individuals such as Ambassador Harold Hilgard Tittmann, modernity in Haiti entailed the technophilic embrace of "progress" under U.S. direction as well as racial "whitening." For the United States progress in Haiti meant acquiescence to its Cold War agenda. This involved better infrastructure and submissive governmental stability to ensure hemispheric security or more properly hemispheric control. "Whitening" was also a facet of modernity and progress because of American acceptance of a racial hierarchy with whites at the apex. Thus, the "whiter" Haitians could become the more advanced they would be, even as they would never be totally white and were therefore subject to U.S. rule. Under Estimé the Haitian elite challenged the U.S. mandate to define modernity and progress. Estimé's conception of modernity entailed an acceptance of capitalism and urbanism but was explicitly opposed to U.S. intervention in Haitian governance. Estimé refuted "whitening" through his embrace of noirisme. For Estimé modernity meant urban development and a proud assertion of blackness. For the underclass, peasants and workers, modernity was often conceived of as an affliction rather than equated with progress. It was expressed in terms of a malicious "tiger car" or locust-like government land appropriation programs. Like Estimé the underclass accepted noirisme rather than "whitening," but they did so mainly to attack the class schism. The United States, the Haitian Government, and the Haitian people clashed 
over definitions of modernity, as well as who was empowered to define it, and their struggle was played out primarily within the rhetoric of noirisme.

The term noirisme and its various derivations so prevalent in the opening of this work is taken from the works of Jacqueline Lamartinière and David Nicholls. ${ }^{5}$ They used it to designate a uniquely Haitian political and social rhetoric tied to blackness. Noirisme has been a facet of national identity throughout Haiti's history as an independent nation. However, it came into institutional discourse by way of the ethnological movement and negritude writings of post-occupation Haiti. Since then, scholars such as Lamartinière and Nicholls have explored its many nuances. It was a black consciousness, which linked democracy and self-rule to the black masses of Haiti. It adhered to a dichotomy between black and mulatto in which mulattos were seen as partners of foreign interest antagonistic to the general populace. However, noirisme was complicated by class. As it was an ideology concerned with the masses in opposition to the elite, it could easily be construed as essentially Marxist. Indeed many, even most, noiristes were socialists. However, a good number of them were doggedly anti-red, Estimé being an example. Thus, the uniting factor of noirisme was blackness. Yet blackness in Haiti is not necessarily a simple matter either. A phenotypicaly black person could be labeled a mulatto and vice versa depending on their socio-economic position. The Haitian proverb "Mulat pov se neg, neg rich se mulat" (a poor mulatto is black, a rich black is mulatto) describes the situation aptly. Whether Haitians sought to be identified as mulatto or black was a matter of historical

\footnotetext{
${ }^{5}$ Jacqueline Lamartinière, Le noirisme: essai sur la negritude et son utilisation dans le contexte Haïtien (New York, 1976) and David Nicholls, From Dessalines to Duvalier.
} 
contingence and was linked to dominant trends in science and literature. In the climate of scientific racism Haitians in general sought to "redden" themselves and claim a mulatto identity. "Reddening" was essentially equivalent to "whitening." However, "whitening" was unacceptable in a nation forged in opposition to the whiteness, which served as a justification for the slave system. Yet blackness was not a viable option prior to the occupation because blackness was equated with degeneracy. Hence Haitians tried to "redden" themselves to erase blackness because to do so did not fundamentally contradict Haitian nation building. When the theories informing scientific racism were refuted in literature and politics, Haitians claimed a black identity.

Haiti was and still is a nation extremely conscious of its history. As Brenda Gayle Plummer puts it "Haitians preserved a sense of historic grievance, receptivity to a stylized political rhetoric, and a feeling of inclusion-whether enjoyed or regretted-in a closed society." For many noiristes as well as their opponents "Haitian history itself came to have [an] immediacy...that Southern history still has for unreconstructed greatgreat-grandsons of the Confederacy."7 Noirisme looked inward and drew upon Haitian history and its symbols for political and social ends. This appropriation of symbols was and remains an important facet of Haitian history.

Symbolic discourse in Haiti was all the more important because of the nation's extremely low literacy rate. In 1950 Haiti was 89.3 percent illiterate, the highest rate of

\footnotetext{
${ }^{6}$ Brenda Gayle Plummer, Haiti and the United States: The Psychological Moment (Athens, GA, 1992), p. 26 .

Ibid.
} 
illiteracy in Latin America and the Caribbean by far. ${ }^{8}$ Even after the Duvalier regime had ended in 1986, Haiti retained an 85 percent illiteracy rate. ${ }^{9}$ To this day, more than half of Haiti's population is illiterate. The political and social discourse in newspapers was for the consumption of the elite. The primary newspapers were written in French, which was a language that the general populace of Haiti simply did not speak and certainly did not read. From the occupation on, Haitian papers carried articles and advertisements in English eliciting American hegemony and further divorcing them from the common Haitian. Aside from the elite, the only people who engaged in politics in a written form were the members of the undersized middle class. At best this middle class constituted 6.7 percent of the populace and was in effect a part of the elite, a position they consolidated under Estimé. ${ }^{10}$ As plutocratic as the Haitian elite had proved themselves to be, the fact remained that with enough machetes the peasantry could cut them down from their elevated position. One need only look as far back as the dismemberment of President Sam in 1914 for an example of the peasantry‘s ability to bring about change violently. Thus it was in the interest of the elite to adopt the symbols of Haitian history, just as it was in the interest of the general population to invoke the very same symbols for their purposes. For example, the elite of Haiti could adopt Charlemagne Péralte or Toussaint l'Ouverture as defenders of Haitian autonomy against imperialism, just as the masses could adopt them as peasant freedom fighters.

\footnotetext{
8 Statistical Abstract of Latin America, $10^{\text {th }}$ edition (Los Angeles, 1966), p.90. Guatemala had the next highest illiteracy rate at 62.1 percent.

"Plummer, Haiti and the United States, p. 219.

1" Various sources place the elite at anywhere from 2 to 20 percent of the population. 20 percent is an outrageous claim and 2 percent is unlikely. Most scholars and government and non-government agencies place it between 5 and 10 percent. See for instance Magloire, Plummer, Dupuy, Nicholls, and Baguidy.
} 
They could be used to justify elite hegemony within Haiti in opposition to outside forces and they could also be used to justify resistance to elite hegemony within Haiti. This fairly convoluted symbolic battlefield was the essence of Haitian politics and would bring Dumarsais Estimé to power in 1946. ${ }^{11}$

Previous depictions of Haitian history have not explicitly examined Haiti under Estimé. There are a few Haitian works about Estimé that serve to underline his importance as a symbol within Haitian politics and praise his memory, but they are markedly hagiographic in tone. ${ }^{12}$ Many other works recognize the significance of the period but treat it as part of a trajectory leading up to the Duvalier regime. Excluding its treatment as a brief stop on the road to Papa Doc or as a period of benevolent black rule (in the case of Haitian works), the Estimé presidency remains a hole in Haitian historiography. Even an otherwise excellent recent work on Haiti could claim "From the beginning of the occupation to the ascent of Francois Duvalier, the United States exerted enormous and unchallenged influence in Haiti." 13 The timeline of Haitian history emphasizes the revolution, the occupation, and the Duvalier regime almost exclusively, so the purpose here, if nothing else, is to add a new watermark to the traditional outline. The Estimé presidency undoubtedly served as a catalyst to the rise of Francois Duvalier. In fact Duvalier's rise to power was in many ways contingent

\footnotetext{
${ }^{11}$ For an account of symbolic discourse in the Haitian religious context see Terry Rey, Our Lady of Class Struggle: the Cult of the Virgin Mary in Haiti (Trenton, NJ, 1999).

${ }^{12}$ See Lucienne Estimé, Dumarsais Estimé: Dialogue avec mes souvenirs (Port-au-Prince, 2001), Joseph Baguidy, Dynamique d'une révolution: 1946 à Haïti (Berne, Switzerland, 1972), Jean Magloire, Pour défendre la memoiré de I'llustre président Dumarsais Estimé (Port-au-Prince, 1957), and Paul Deschanel, Hommage de la jeunesse intellectuelle du Nord au président Dumarsais Estimé (Port-auPrince, 1947).

${ }^{13}$ Paul Farmer, Aids and Accusation: Haiti and the Geography of Blame (Berkeley, CA, 1992), p. 183. [emphasis mine].
} 
upon Estimé. However, Estimé also served to remind the United States that the "racial complications" of the occupation had never disappeared and that Haiti was capable of contesting U.S. hegemony. For it was under Estimé that the relationship between race and economics was put to the forefront of politics, forcing the United States to contend with it not only at home but in its foreign relations as well. It was also under Estimé that the divergent perspectives of the elite and the peasantry came to a head. 


\section{The Roots of Noirisme}

To understand race in the Haitian context and to trace the rise of U.S. hegemony it is necessary to examine the historical background of mid-twentieth century Haiti. In 1522 the first slave rebellion in the Americas took place on the island of Hispaniola, home to the modern countries of Haiti and the Dominican Republic. ${ }^{14}$ Indeed violent resistance to oppression based on racial and economic division would continue to characterize Haitian history. The slave system which made Saint Domingue the "pride of the Antilles," was intimately connected to definitions of 'race.' The upper class whites who controlled the plantation system, as well as the colonial administrators of Saint Domingue were known as the grands blancs. The owners of the plantations tended to be absentee landlords. Planters remained to oversee the operation of the slave plantations. The more marginalized whites of the island were known as petits blancs. They were comprised of lower and middle class whites who tended to involve themselves with various facets of urban commerce. The affranchis were free people of color, most of whom tended to engage in occupations similar to those of the petits blancs. Not surprisingly, the petits blancs and the affranchis were often in conflict. The racism of the slave system transferred over to the public sphere such that even those affranchis in a superior economic position to the petits blancs were subject to a racial hierarchy which placed them below anyone with white skin.

\footnotetext{
${ }^{14}$ Harold Hoetink. " 'Race' and Color in the Caribbean" in Caribbean Contours ed. Sidney Mintz and Sally Price (Baltimore, 1985), p. 59.
} 
The plantation economy was reliant upon the labor of black African slaves and their descendants. These slaves were organized into atliers, or work groups. The atliers were comprised of slaves thought to be particularly suited to various tasks, who were put to work accordingly. For instance the slaves considered to be the most robust were organized into an atlier responsible for the heaviest labor. Children and pregnant women were placed in a work group designated with less laborious tasks, such as weeding. The head of the attiers was the commandeur, who was generally a slave. Slaves were further divided between house and field slaves, with field slavery being the more physically rigorous of the two. Field slavery, in the case of sugar production, was also divided between field and factory. The head of the refinery was the maitre sucrier, who was also generally a slave. The matre sucrier and commandeur were often in conflict because their appointments could be interchanged. These divisions, based on race and occupation, contributed to the maintenance of the plantation structure and the circumscribed position of the slaves. This was necessary, in the eyes of the planters, to maintain control. The divisions fixed in the slave system set a precedent for the future governance of the island.

The colonial masters of Saint Domingue sat upon a precarious throne. The slave population greatly outnumbered them. In order to reap the profits of the slave system, the planters needed to maintain their position of dominance. This was achieved through physical and mental torture and adherence to a racial hierarchy. Race and the characteristics associated with it provided an ideological basis for the justification and maintenance of the slave system beyond the economic. The characteristic that most readily distinguished a slave from a planter was skin color. Division based upon skin 
color also applied to the free black population of the island, which was not granted the same freedoms as the white population. In this sense race became of greater significance than class in economic disputes between blacks and whites. The elite of Saint Domingue employed race as the central feature of their domination. In this they were not unique; rather they maintained a tradition of racial hierarchies, which was readily at their disposal.

As noted, in order to maintain dominance there had to be a mechanism of control. Hegemony was that mechanism of control and is used here in an essentially Gramscian scheme. Hegemony is control outside the bounds of direct state intervention achieved primarily through the presentation of power and the perception of subjects that this power is immutable. Antonio Gramsci is particularly applicable to this work because he was especially concerned with symbolism and ideology as they related to class interaction. Gramsci claimed that through hegemony the elite controlled "not only the means of physical production but the means of symbolic production as well." ${ }^{5}$ Control of symbolic production is achieved through "ideological state apparatuses" which secure the "active consent of subordinate groups to the social arrangements that reproduce their subordination." ${ }^{\prime 16}$ Control of symbols allows the elite to define reality and thus relegates resistance and the desire for freedom to the realm of the impossible. This in turn leads people to accept their position in society and see the structures of oppression as natural. This idea builds directly on Karl Marx"s concept of "false

15 James C. Scott, Weapons of the Weak: Everyday Forms of Peasant Resistance (New Haven, CT, 1985), p. 315.

16 James C. Scott, Domination and the Arts of Resistance: Hidden Transcripts (New Haven, Ct, 1990), p. 73. 
consciousness." If the elite have the ability to manipulate the lower classes then the lower classes must be successfully deceived, making them "falsely conscious." In the Gramscian scheme liberation from mental slavery is achieved when a Leninist intelligentsia sheds false consciousness and rises from the people to take control of the means of symbolic production. For Gramsci the Leninist intelligentsia is most likely to be born out of "organic intellectuals." "These organic intellectuals are distinguished less by their profession, which may be any job characteristic of their class, than by their function in directing the ideas and aspirations of the class to which they organically belong." 17

Organic intellectuals are enabled to mediate class antagonism because "a hegemonic ideology must, by definition, represent an idealization, which therefore inevitably creates the contradictions that permit it to be criticized in its own terms." 18 In other words, any given hegemonic ideology contains the seeds of its own destruction. In criticism of Gramsci, James Scott claims that liberation from hegemony is not achieved through the auspices of an intelligentsia but through "everyday resistance." This "everyday resistance" ranges from symbolism in music and folklore to work slow downs. "Everyday resistance" is the means by which the peasantry en masse, rather than an intelligentsia, engages in dialogue with the elite. This dialogue in turn informs hegemony, which is therefore rendered amorphous. It then stands to reason that through hegemonic dialogue it is possible for the oppressed to liberate

\footnotetext{
$1^{1}$ Antonio Gramsci, Selections from the Prison Notebooks (London, 1971), Translated and edited by Quintin Hoare and Geoffrey Nowell Smith, p. 3.

${ }^{18}$ James Scott. Weapons of the Weak, p. 317.
} 
themselves without the aid of an intelligentsia. While Scott claims to "stand Gramsci's analysis of hegemony upside down...,"19 he essentially just expands on Gramsci's concept of organic intellectuals. That is, for Scott there need no longer be a vanguard of the underclass to lead it towards freedom because "“falsely conscious' subjects are quite capable, it seems, of taking revolutionary action."20 The implication of course is that the underclass is not falsely conscious. The primary conflict in the theories of Gramsci and Scott is that for Gramsci "all men are intellectuals...but not all men have in society the function of intellectuals",21 whereas for Scott "all men are intellectuals." As such, Scott does more to expand upon Gramscian analysis than to invert it and is useful for that reason. The abstract principles thus presented are particularly interesting when applied to Haiti.

While overt resistance tends to be stressed in Haitian history, with good reason, the election of Estimé can be considered the culmination of "everyday resistance." That is, the fact that the president of Haiti would have to be black in 1946 was not a function of elite mechanisms of control but a reaction to them. It was because the peasantry in concert with students and social organizations professed a noiriste doctrine and supported it through demonstrations and unrest that the so called "revolution of 1946" was a given. The agency accorded the general population of Haiti in bringing about the "revolution of 1946" was based upon their ability to transform "everyday resistance" into outright rebellion. The people were not led through their troubles by

\footnotetext{
${ }^{19}$ James Scott, Domination and the Arts of Resistance, p. 90.

${ }^{20}$ Ibid., p. 78.

${ }^{21}$ Antonio Gramsci, Selections from the Prison Notebooks, p. 9.
} 
great men but rather created great men as symbols to aid them in overcoming their plight. An example of this is the Haitian revolution. If the slaves of Saint Domingue had simply to rely upon Toussaint l'Ouverture's abilities as a leader they would likely have failed in liberating themselves from slavery. Toussaint l'Ouverture is remembered as a great man not because he organized slaves towards their freedom but because their own achievements can be neatly symbolized in the person of Toussaint.

The Haitians who liberated themselves from slavery through revolution conceived of their struggle in terms of race as illustrated by Jean-Jacques Dessalines:

The whites from France cannot hold out against us here in Saint Domingue... when the French are reduced to small, small numbers, we will harass them and beat them; we will burn the harvests and then take to the hills. They will be forced to leave. Then I will make you independent. There will be no more whites amongst us. ${ }^{22}$

The slave system had been so racialized that independence was equated with the elimination of whites. In expunging whiteness, the roughly five-hundred Poles and the small contingent of Germans who had aided the Haitians in the revolution and remained on the island were initially defined as black though they were phenotypicly white. ${ }^{23}$ After the death assassination of Dessalines in 1806, their descendants became mulattos in the eyes of the general populace. Independence was achieved in 1804 making Haiti the first and only slave society to liberate itself "from below." It existed as something of a proud anachronism. Haiti's successful revolution was the seed of "terrified consciousness," or the recognition that the imperial hold on slave societies was subject

\footnotetext{
22 Quoted in Carolyn Fick, The Making of Haiti: The Saint Domingue Revolution from Below' (Knoxville, TN, 1990), p. 212.

¿3 David Nicholls, From Dessalines to Duvalier, p. 265.
} 
to the possibility of overthrow from within. ${ }^{24}$ Terrified consciousness fueled the nonrecognition of Haitian independence on the diplomatic front. Planters throughout the Americas recognized that Saint Domingue was not the only island where the whip could be repaid through revolution. In 1826 U.S. Senator Thomas Hart Benton gave voice to such fears with " we receive no mulatto consuls or black ambassadors from [Haiti]. And why? The peace of eleven states will not permit the fruits of a successful Negro insurrection to be exhibited among them.",25

While slave societies feared the example of Haiti, the people of the nation took great pride in their history. This pride was tied to race and nourished both the noirisme and the schism between black and mulatto, which characterized subsequent Haitian history. Though freedom and autonomy were tenuous, Haitians held to them dearly. An antagonistic relationship between the elite and the general population served to stifle the freedom Haitians had fought for in the revolution. An example of the opposition of black and mulatto is clear in the division of post-revolutionary Haiti into two kingdoms. The Northern half of Haiti was a black kingdom under Henry Christophe and the Southern half was a republic under mulatto Alexandre Pétion. The division between black and mulatto was not simply a matter of ideology but a foundation for tangible and enduring division within Haiti as well. Therefore race and the characteristics associated with it had a powerful resonance for the average Haitian. Even after Jean-Pierre Boyer ostensibly reunited Haiti in 1820 “The ever present colour

\footnotetext{
${ }^{24}$ Franklin Knight, "The Haitian Revolution," American Historical Review, vol. 105, (Feb. 2000), p.113. ${ }_{25}$ Quoted in Elizabeth Abbott, Haiti: An Insider's History of the Rise and Fall of the Duvaliers (New York, 1991), p. 18.
} 
question ... served to divide Haitians into hostile groups and gave politicians a stick with which to beat their opponents." 20

Throughout the nineteenth and early twentieth century, Germans, French, and Americans attempted to intervene in the political and economic affairs of Haiti, threatening the country's sovereignty. But the most explicit challenge to Haitian autonomy came in the form of United States marines landing on the island in 1915. The U.S. occupation of Haiti from 1915-34 had a profound impact on the worldview and social structure of Haiti. One consequence of the occupation was the restructuring of the Haitian concept of race. "'Color' or 'race'... is a function of existing modes of perception that are themselves a historical and cultural product, not a genetic actuality." 27 In post-revolutionary Haiti and up to the occupation, the perception of race, though nebulous, was essentially a dichotomy of opposition between black and mulatto.

Race was also of political and social significance in the United States. However, U.S. constructions of race were different from those of Haitians. For Americans race was a matter of black and white. During the occupation American conceptions of race were imposed on the Haitian dichotomy. The meeting of Haitian and American perceptions of race necessitated their transmutation. This perhaps oversimplifies the complexities of American and Haitian conceptions of race but it serves to illustrate their significance. Race is employed here in order to elucidate the connections between racial constructions and imperial politics. As noted, Haitians and Americans had

\footnotetext{
${ }^{20}$ David Nicholls, From Dessalines to Duvalier. p. 14

${ }^{27}$ Sidney Mintz. Caribbean Transformations ( New York, 1989), p. 315.
} 
constructed racial orders that were tied to identity and politics and the occupation catalyzed a re-evaluation of these orders.

One example of the significance of race in U.S.-Haitian relations can be seen in the imperial contest between Germany and the United States. By 1914 the Germans had established a permanent colony within the nation of Haiti. Some Germans married Haitian women in order to get around laws prohibiting foreign ownership of land. In 1912 a German school was opened in Port-au-Prince in order to " "Germanize the descendants of Germans established in Haiti.",28 Germans controlled eighty percent of Haitian commerce in $1914 .^{29}$ Germany was also "not averse to sending warships to collect unpaid debts." ${ }^{30}$ The Germans were quite willing to engage in gunboat diplomacy. Thus, Germany had a good grounding to establish itself as the primary foreign power in Haiti. However, the United States was also attempting to exert its influence on the island. It should be noted that France and Britain also showed an active interest in subordinating Haiti. France in particular had many economic, cultural, and historical links to Haiti to aid them in their neo-colonial project. Yet just prior to the occupation the United States and Germany were in the best position to exert influence over Haiti. As Hans Schmidt explains "Germany, as a nascent and aggressive imperial power, was considered by the United States as its chief rival in the

\footnotetext{
${ }^{28}$ Quoted in Hans Schmidt, The United States Occupation of Haiti 1915-1934 (New Brunswick, NJ, 1971), p. 34.

29 Ibid., p. 35.

30) James Fergusson, A Traveller's History of the Caribbean (New York, 1999), p. 214.
} 
Caribbean." 31 This contested influence placed the United States in direct opposition to Germany.

Yet even in the most derisive U.S. government documents the Germans were simply referred to as "German." The Germans living in Haiti were considered viable opponents. The U.S. despised their attempts to assert themselves in the economic and political fields of Haiti and depicted them as the real power behind Haitian resistance to U.S. encroachment. While the U.S. occupation was not driven wholly by conceptions of race, racist paternalism was the justification for it. Economics were certainly a central issue in the occupation and were the primary reason that the United States took an interest in Haiti. However, the reason that American officials considered the Haitian economy unstable was because they viewed Haitians as depraved and ignorant. The U.S. sought to make it impossible for the finances of Haiti "to be considered and counted on as security for loans made by those who consider the financing of a revolution a legitimate business enterprise." 32 The quote refers to Germans who were believed to have been profiting from political unrest. An American official described the mechanics of this process in:

Revolutionary movements were financed by foreigners who, when approached by a leader of an incipient movement, would agree to lend funds and would buy so-called 'revolutionary bonds' at perhaps ten cents on the dollar, with the understanding that if the revolution was brought to a successful conclusion, the bonds would be redeemed. ${ }^{33}$

\footnotetext{
${ }^{31}$ Hans Schmidt, The United States Occupation of Haiti, p. 34.

32 Ibid., p. 320.

${ }^{33}$ John Allen quoted in Robert and Nancy Heinl, Written in Blood: the Story of the Haitian People 14921995 (Lanham, MD, 1996), p. 338.
} 
In order to achieve economic balance the United States needed to impose "stability" in a place they held to be unstable because of its black population and the Germans they believed to control it. The occupation was a battle with Germany for hegemony, within which Haitians were regarded as little more than pawns.

References to Haitians in U.S. government documents demonstrate the venomous characterizations used to justify intervention. Secretary of Legation Beale Davis referred to Haitians in a memo to the Secretary of State variously as "half-starved natives," "utterly ignorant," and "armed rabble" which was capable of becoming "mad from the sight of blood." 34 The context for this description was the dismemberment of the president of Haiti by a mob of Haitian citizens. This incident was the impetus for the occupation of the island. Perhaps Davis's shock at the immolation of President Sam is understandable. Yet his concerns after the incident present a classist and racist perspective typical of U.S. officials and military personnel at the time. He states:

Following the American intervention, and as soon as the ignorant classes found that they were not to be made slaves and their lands confiscated as the politicians, seeing in foreign intervention an end of the conditions which had permitted their exploitation of the country for personal gain, had taught them to believe, conditions rapidly began to improve. $^{35}$

Here Davis offers a detached and paternalistic view of Haitian politics. He imparts recognition of the schism between blacks and mulattos and suggests that the mulatto elite had fooled the "ignorant classes" into believing that the U.S. sought to make them slaves and take their land. He then slates the occupation as benevolent such that after Haitians realized the United States was not there to enslave them the situation was

${ }^{34}$ R.B. Davis, FRUS: 1916, p. 318.

${ }^{35}$ Ibid., p. 319. 
ameliorated. This ignores the fact that Haitians did connect labor forced on them by U.S. marines with slavery and many became Cacos rebels in order to fight the United States. Further, the Cacos were primarily composed of the peasantry, or "ignorant classes." At the ground level, where Haitians and marines interacted, American marines "insisted on treating all Haitians of whatever colour as "niggers." 36

American conceptions of race served as a rationalization for intercession in Haiti. If Haitians were simply "utterly ignorant," "half-starved natives" based on their black skin, then U.S. intervention could be slated as a benevolent undertaking with the goal of restoring order. Rather than allow Haitians to remain "mad from the sight of blood" the U.S. government would "aid the Haitian people to free themselves from the hopeless conditions which continued revolution and a policy of despotic militarism had produced." ${ }^{37}$ Such rhetoric was common in the climate of the "white man's burden." Intrinsic to the "white man's burden," which took its name from a Rudyard Kipling poem, was a pro-imperialist call to arms favorable of "civilizing" dark skinned peoples who were considered inferior to light skinned peoples. Ostensibly the United States sought to restore order to Haiti through the occupation. However, the American conception of the root of Haitian disorder was based on racism. Because Haitians were "utterly ignorant," "blood maddened," "half-starved natives" disorder was their natural state of existence. 1t was therefore the American duty to take up the "white man's burden" and "civilize" the supposedly depraved Haitian people.

\footnotetext{
${ }^{36}$ Nicholls, From Dessalines to Duvalier. p. 142.

${ }^{37}$ Davis, FRUS: 1916, p. 319.
} 


\section{The Appropriation of Blackness}

The U.S. occupation and its racial constructions recast Haitian identity. Mulattos who had been at the apex of the Haitian racial hierarchy were labeled as black and responded with the assertion of black unity. "The Americans unintentionally succeeded where Dessalines had failed, in uniting all Haitians under the name 'black." 38 One aspect of this new black identity was the ethnological movement, founded by Justin Chrysostome Dorsainvil, Dr. Arthur Holly, and Dr. Jean Price-Mars. They stressed that the road to a new black identity would take the form of education, religion, and language. The road would also have to originate in Africa. The ethnological movement maintained that "...it is impossible to penetrate the mentality of the Haitian people without a profound study of their African origins." 39 Hence education had to stress Africa; Vodou was favored in the realm of religion; and Creole in the realm of language. Haitians were critical of American education programs, which they considered too technical and materialistic. Through the efforts of the Minister of Public Instruction, Dantes Bellegarde, "Haitian students began to learn history not so much from French and European traditions, but rather from an African perspective." ${ }^{, 0}$ Arthur Holly and Jean Price-Mars were critical of Vodou as a religion but appreciated it as a resonance of African culture. The ethnological movement

\footnotetext{
${ }^{38}$ Nicholls, From Dessalines to Duvalier. p. 142.

${ }^{39}$ Ibid., p. 143.

${ }^{40}$ Leon Pamphile, Haitians and African Americans: A Heritage of Tragedy and Hope (Gainesville. FL, $2001)$, p. 109.
} 
considered Creole an intrinsically valuable language rather than as a mark of ignorance. $^{+1}$

However, the ethnological movement, in a sense, denied the very things it sought to proclaim. The African past of Haiti was either stressed for its Western components or forced into a Western mold. Price-Mars, for instance, relied upon ethnological and anthropological works emanating from the French academy in formulating his vision of Africa. ${ }^{42}$ These works embraced a euro-centric hierarchy of "civilization" and stressed similarities between African and Western traditions to impart the potential of Africans for "civilization" while at the same time underlining their "primitive" nature. ${ }^{43}$ Though, Price-Mars had little to choose from as far as academic sources on Africa, he prefigured Estimé in his embrace of "progress" linked with noirisme. The study of Africa on its own terms was not embraced and it remained a dark continent of drums and dancing even as these were now ostensibly respected (provided they could be paralleled with Western practices).

The ethnological movement influenced negritude. This was a literary movement that stressed a unique black spirituality. Thus, blacks were considered a distinctive race with a unique spiritual heritage. Like the ethnological movement, negritude also emphasized African roots. Also like the ethnological movement, these African roots were imagined from a Western perspective and rarely distinguished

\footnotetext{
${ }^{41}$ See Leon-Francois Hoffman, Haïti: couleurs, crovances, créole (Port-au-Prince, 1990).

${ }^{42}$ Magdaline Shannon, Jean Price-Mars, the Haitian Elite and the American Occupation, 1915-35 (New York. 1996), p. 63, 75-76.

${ }^{43}$ See for instance Joseph Deniker, Les Races et les peoples de la terre: elements d'anthropologie et d'ethnographie (Paris, 1926), Alexandre Le Roy, La religion des primitives (Paris, 1909), and Maurice Delafosse, Les noirs de l'Afrique (Paris, 1922).
} 
between the myriad cultures of Africa. At best negritude unified blacks, provided a rich and self-affirming literature, and asserted a proud identity in the face of the occupation. At worst it simply endorsed the racialized divisions imported during the occupation. Within the reaction to the occupation expressed in the ethnological movement and negritude, the elite of Haiti were enabled to appropriate blackness while maintaining the same divisions that had plagued Haiti throughout its history. In the socio-political realm "the ethnological movement in particular contributed to a reinvigorated noiriste ideology, in which the black legendary view of the past was enforced by the new racialism of negritude., ${ }^{44}$

A similar appropriation of blackness was underway in the United States and the meeting of the two further illustrates the nature of the Haitian version. The Universal Negro Improvement Association (UNIA) was active in Haiti, and at a 1920 New York convention the Haitian delegate invoked race and "spoke of the revolutions instigated in that country by white men." ${ }^{45}$ Speaking of the Haitian people and soliciting the aid of American blacks, he went on to state "actual independence they do not have, but they hoped to posses it ... with God's help and the aid of black people from this country and other parts of the world." 46 The UNIA was not the social and economic force in Port-au-Prince that it was in Harlem and its Haitian activity remained

\footnotetext{
${ }^{44}$ Ibid, p. 163.

${ }^{45}$ Robert Hill ed., The Marcus Garvey and Universal Negro Improvement Association Papers (Los Angeles, 1983), v. 2, p. 531.

${ }^{40}$ Ibid.
} 
essentially intellectual. ${ }^{47}$ The primary aid, if it can be characterized as such, that the UNIA accorded Haiti came in the form of Garvey's relatively frequent reference to the island and its symbols in his speeches. Alternating between third and first person Garvey stated "...the only regret Marcus Garvey has now [is] that he was not born in the days of slavery, when he would have taken up the sword like Toussaint l'Ouverture to free myself out of a slavery that I did not bring upon myself."48 He always depicted l'Ouverture as the driving force behind the revolution and claimed him for the UNIA as a symbol of eventual triumph. Garvey had a reverence for Toussaint l'Ouverture that he denied Haitians in general. In a 1924 speech Garvey stated:

Because Haiti, little Haiti, has had her little political troubles...our army and navy proceeds to invade the little country and [est]ablish jurisdiction over it. But [Fr]ance, which troubles the peace of the [wo]rld, is allowed to do as she pleases. [Ho]w? Because France represents pow[er.] France represents strength, while [Hai]ti represents nothing. ${ }^{49}$

Although he laments the occupation, the underlying message is an admonition of Haiti for not being stronger. However, it is unlikely that Haitian members of the UNIA would have been particularly disturbed by this speech. This is because Garvey compares Haiti to France and within Haiti the UNIA was comprised of the elite. In an interview with the New York Sun, the Haitian minister "corroborated the attitude" of a

\footnotetext{
${ }^{47}$ For the social and economic aspects of UNIA activities within the United States see lrma WatkinsOwens. Blood Relations: Caribbean Immigrants and the Harlem Community, 1900-1930 (Indianapolis, 1996), and Winston James, Holding Aloft the Banner of Ethiopia: Caribbean Radicalism in Early. Twentieth-Century America (New York, 1999).

${ }^{48}$ Robert Hill ed., The Marcus Garvey and Universal Negro Improvement Association Papers (Los Angeles, 1986), v. 5, p. 140.

${ }^{49}$ Ibid., p. 529.
} 
Mr. Candice, from Guadalupe, that "II am black, but I am French first." "50 Candice was responding to Garvey's Afro-centrism from the standpoint of a Francophile. In so doing he was also giving voice to the opinion of the Haitian elite.

The occupation had not fundamentally altered the American perspective on race. All Haitians were still considered black and therefore inferior. However, the United States recognized that race was tied to class in Haiti and that mulattos were traditionally better off financially than blacks and more favorable to U.S. interests. In order to stabilize the position of the mulatto elite and thereby secure hegemony, the U.S. completely reorganized the Haitian military. The gendarmerie, renamed the Garde d' Haïti in 1928, was centralized, weakened, and subordinated to the Haitian government. This served to stabilize Haitian - Dominican relations, or rather to better the U.S. position in both nations. It also allowed for a more predictable political climate, which was a facet of the stability necessary for U.S. hegemony. The fact that the Garde d' Haiti did not force conscription had the result of its being comprised chiefly of proAmerican Haitians. Even after the withdrawal of U.S. troops in 1934, the Garde d' Haiti could be described in these terms: "its spirit, morale, and military training are American." ${ }^{, 51}$ The occupation of Haiti by thousands of U.S. marines had an indelible effect on the island. This was expressed in an altered infrastructure, military, and, most significantly, Haitian worldview.

\footnotetext{
${ }^{50}$ Robert Hill ed., The Marcus Garvey and Universal Negro Improvement Association Papers (Los Angeles, 1985), v. 4, p. 32.

${ }^{51}$ Petrus Calixte, Haiti: The Calvary of a Soldier (New York, 1976), p. 29.
} 
Immediately following the occupation, the "stability" and "democracy" necessary for U.S. hegemony appeared to be firmly in place. In practice, "stability" and "democracy" amounted to mulatto dictatorships, which were characterized by greed and American accommodation. U.S. hegemony appeared to be firmly established. The United States simply needed a favorable Haitian president in office before it could fully withdraw the occupation forces. They found such a man in Stenio Vincent. President Vincent actually came to power on a nationalist platform, which opposed the occupation. Vincent was, however, quite favorable to U.S. investment and business ventures in Haiti. Vincent was also highly suspicious of blacks and particularly those blacks enlisted in the Haitian military. In fact, Vincent maintained a private security force, a tactic that Duvalier would later employ with the Tonton Macouts. The subordination of the new Haitian military, as well as Vincent's disregard for black Haitians, was demonstrated in 1937. Haitian cane cutters who had been expelled from Cuba sought work in the Dominican Republic. Within Cuba, Haitians, along with other Antillean laborers, became the foil of nationalist politics. "Amid rising unemployment and social turmoil, the immigrants became a visible target for the nationalists' desire to alleviate the situation of native workers. ${ }^{, 52}$ Within the Dominican Republic they were accused of banditry, cattle-theft and were generally despised. Haitian national identity was equated with blackness. Dominican national identity focused on the denial of blackness. The presence of thousands of black cane cutters in the Dominican Republic was therefore problematic for Dominicans. Rafael

\footnotetext{
52 Alejandro De La Fuente, A Nation For All: Race, Inequality, and Politics in Twentieth-Century Cuba (Chapel Hill, NC, 2001), p. 103.
} 
Trujillo, dictator of the Dominican Republic, addressed the "Haitian problem" with brutal force. "Trujillo's antidote was to begin bloodletting, and the rivers of blood that flowed were Haitian." ${ }^{, 53}$ Estimates of the death toll range from 10,000 to 30,000. In any case, the incident was one of extreme brutality. The Haitian military was unable to retaliate and the Haitian government accepted a monetary concession.

The Vincent administration ended in 1941, and Elie Lescot gained the Haitian presidency. Lescot continued Haitian accommodation to U.S. hegemony. In fact, Lescot declared war on the Axis powers five hours before the United States. ${ }^{54}$ Haitians saw Lescot as a successor to Vincent. An American newspaper article captures their reaction to his "election:" " Riots occurred last week when large crowds demonstrated at the Congress building...in protest against the Lescot candidacy, which was said to have been supported by Vincent." ${ }^{55}$ Regardless of popular disaffection, Lescot supported a number of American development programs. He granted land for sisal cultivation to the Societe Haïtiane-Americaine Development Agricole (SHADA), which the U.S.-controlled Import-Export bank funded. SHADA had a predominantly American administration and tended to fund programs to produce goods to be consumed in the United States. The land given to SHADA in order to provide the United States with sisal products was taken from peasants, who were subsequently displaced. Sisal itself was a hemp substitute used to mainly for rope. Lescot also supported the Cryptostegia project to produce rubber for the war effort. The

\footnotetext{
${ }^{53}$ Abbott, Haiti: An Insider's History p. 49.

${ }^{54}$ Ibid, p. 53.

55 "Lescot Minister to U.S., Voted Haitian President," Crumbie Papers. MS Group 14.
} 
Cryptostegia project, which took its name from a tree believed to yield cheap rubber failed to produce a significant amount of quality product. An American newspaper observed that "the cryptostegia experiments had become such a by-word for failure the newly-formed Communist party was using them for anti-Yankee propaganda." ${ }^{, 56}$ These programs, which enriched the Lescot administration at the expense of the Haitian people, would become a particular bone of contention during the Estimé administration. ${ }^{57}$ In the cultural realm Lescot launched an "anti-superstition" campaign to repress Vodou and introduced laws defining acceptable cultural practices. This entailed the confiscation and burning of drums and ritual paraphernalia and criminal codes against Vodou.

Haitians hostility to the policies of Lescot and widespread anti-Lescot sentiment resulted in protests and strikes. In the United States the unrest within Haiti was watched with concern. From the U.S. perspective "the 'Black Republic' of Haiti faced a future even darker than her three million people ( $95 \%$ pure Negro)" because "bottomdog conditions on U.S. Caribbean doorstep were piling up unrest, fertilizing soil for Red propaganda." ${ }^{, 58}$ Americans linked the noirisme driving popular agitation for elections directly to communism. In connecting race to the communist party the United States press was actually promoting the symbolic discourse of the peasantry, though their purpose was quite the opposite. The Communist party as an official body within Haiti was predominantly comprised of elite liberal mulattos. The most notable of these

\footnotetext{
56 "Black Soil for Reds," Pathfinder, 27 February 1946.

${ }^{57}$ Charles Hauch Memorandum of Conversation, FRUS: 1946, p. 734.

58 "Black Soil for Reds," Pathfinder, 27 February 1946.
} 
was Jacques Roumain who founded the Haitian Communist Party in $1934 .^{59}$

Communism was attractive to liberal mulattos because it attacked the racism of noirisme. Roumain "claimed that the colour problem in Haiti was of exceptional importance because it was the means whereby politicians, both black and mulatto, were able to divert attention from the class struggle." ${ }^{, 00}$ Communism was also enticing because "false consciousness" justified the current position of the masses, and their liberation was in the hands of the Haitian Intelligentsia, a title members of the party could claim. The communism of Francophile Haitians, who gleaned their theories through dense books and African-American newspaper articles, was actually in opposition to the socialism of the masses. The peasantry did not conceive of the class struggle in the same way that the elite did. While the elite either claimed noirisme as their own or lamented it as a diversion from the issue of class, the masses employed race as their primary weapon against oppression. Hence the communist party within Haiti was opposed to noirisme, while the peasantry adopted it as the means to condemn, among other things, the class schism. Ultimately, the disquiet throughout Haiti culminated in a military overthrow of the Lescot government on 7 January $1946 .^{61}$ U.S. hegemony was manifest in the Haitian elite adoption of organizations like the UNIA and the Communist party. The elite recognized the tension between AfricanAmericans and the state. They also understood the leveling agenda of communism in the U.S. even as they feared it at home. That the Haitian elite adopted the movements

\footnotetext{
${ }^{59}$ Nicholls, From Dessalines to Duvalier. p. 173.

${ }^{60}$ Ibid.

${ }^{61}$ Nicholls, From Dessalines to Duvalier. p. 184.
} 
of the American underclass points to their position vis-à-vis the United States. The ways in which they adopted these movements also points to their recognition of their position in relation to the masses. That is, the Haitian elite appropriated blackness in order to combat U.S. hegemony at the same time that they used it to secure their own. The elite were not completely united in their approach to the problem of opposing U.S. hegemony while maintaining theirs. Conservatives, like Lescot, for the most part accepted U.S. dominance and sought to maintain control in Haiti through direct coercion. Liberals, like Roumain, adopted communism to mute race and claim their mandate as a benevolent intelligentsia. Noiristes like Estimé adopted black nationalism in order to legitimize their modernizing project while distancing themselves from the cold war. By 1946, the Haitian people were most sympathetic to the noirisme espoused by Estimé. In the sense that none of the elite approaches to modernity was particularly favorable to the masses, the support that the masses accorded Estimé was simply the most in line with their own agenda. Within the rhetoric of noirisme, which Estimé had connected himself to, there was space to contest the iniquity of the elite. Ultimately, the disquiet throughout Haiti culminated in a military overthrow of the Lescot government on 7 January $1946 .^{62}$

\footnotetext{
${ }^{62}$ Nicholls, From Dessalines to Duvalier. p. 184.
} 


\section{"The Revolution of 1946"}

1946 saw the victory of noirisme in the political sphere. A political coalition of various radical groups under the collective of Front Revolutionaire Haïtien (FRH) formed to agitate for elections. ${ }^{63}$ The primary concern of the FRH was the election of a black president. "These groups were in general agreement that some radical changes were needed in the country and that these could be carried out only by an authentic representative of the people, that is by a black president." ${ }^{\text {64 }}$ Estimé recognized the importance of race in the election and ran on the slogan "A black man in power." 65 Petrus Calixte also campaigned for the black vote and drew his support primarily from Port-au-Prince and the Mouvement Ouvrier Paysan (MOP). Colonel Petrus Calixte was a black Haitian who rose in the ranks of the Garde d' Haïti. His high rank in the military coupled with his race had earned him the distrust of President Vincent. In the late 1930s he was accused of plotting to overthrow President Vincent and sought exile in the United States. ${ }^{66}$ Calixte returned to Haiti to run on a noiriste platform as Estimé's primary opposition. MOP was a noiriste party founded by Daniel Fignolé in 1946. "Fignolé was proud of his charismatic following among the urban poor of Portau-Prince and called their massed power the "steamroller.", 67 With the steamroller in

\footnotetext{
${ }^{63}$ Ibid.

${ }^{64} \mathrm{Ibid}$, p. 185.

${ }^{65}$ Abbott, Haiti: An Insider's History. p. 56.

${ }^{60}$ Petrus Calixte, Haiti: The Cavalry of a Soldier, p. 127.

${ }^{67}$ Plummer, Haiti and the United States, p. 149.
} 
motion, elections were imminent. Juste Constant ran on a communist platform, representing the liberal wing of the mulatto elite. The more conservative elements of the mulatto elite backed Edgar Numa, a black man. Numa professed an adherence to noirisme but was considered a puppet of the mulatto elite. ${ }^{68}$ Estimé drew his support from the peasantry concentrated in the Artibonite Valley and the North, as well as the very small middle class. Because he was the primary noiriste candidate from the North he enjoyed the support of a large segment of the peasantry, and because he was a moderate he had the urban middle class in his corner. He planned to liberate Haiti from U.S. domination, legislate greater freedoms and embrace modernization as the panacea to the plight of workers and the peasantry. On August 16, 1946 Dumarsais Estimé was elected President of Haiti. ${ }^{69}$ The opposition between mulatto and black had been successfully manipulated to bring Estimé to power. Thus, the Haitian government established after the occupation, once so favorable to U.S. interests, had been inverted. The old mulatto elite was moved from the throne to the court of Haitian governance. The United States no longer had a stable middleman in their relations with Haiti, hence the renewed concern with "racial complications."

Within Haiti the peasantry could celebrate its success in helping bring a black man to power. However, many were initially disappointed that the revolution of 1946 had resulted in a moderate's ascension to power, particularly the urban poor at the helm

\footnotetext{
${ }^{\circ 8}$ Alex Dupuy, Haiti in the World Economy: Class, Race, and Underdevelopment since 1700 (London, 1989), p. 150. The practice of mulattos running a black for office while retaining control of the government was known as politique de doublure.

69 Ambassador Tittmann to Secretary of State, FRUS: 1946, p. 937.
} 
of the "steamroller." Estimé recognized that in order to stop the steamroller he needed Fignolé. Estimé wanted to stop the steamroller because although he embraced noirisme he also embraced capitalism and feared communism as much as the U.S. imperialists he often fought against. Therefore he appointed Fignolé to his cabinet as minister of education. This tactic worked and "Fignolé's acceptance of this deal simultaneously weakened him as an urban leader and sacrificed his following to the new president.,"70 Because Fignolé was willing to give Estimé the benefit of the doubt, his following was willing to put their faith in Estimé. As a concession to the mulatto elite Estimé appointed Georges Riguad minister of commerce. However, he was unable to co-opt Rigaud's following who had remained vocal critics of his administration. The Mulatto elite, who had been divorced from government dominance with the election of 1946, criticized Estimé primarily for his economic policies and his acceptance of noirisme. Since the occupation the mulatto elite had found alliance with U.S. interests lucrative. The autonomy Estimé proposed was in conflict with U.S. interests, so the old guard generally considered him imprudent. The liberals who followed Rigaud felt that Estimé was avoiding the class issue through his espousal of noirisme.

Estimé addressed opposition from liberal mulattos directly. In March of 1947 he managed to pass an anti-communist law. ${ }^{71}$ This was perhaps the one redemptive aspect of his administration in the eyes of the United States. He would later use his opposition to communism as a means to secure U.S. aid for a slum clearing project in Port-au-Prince. Academics commenting on Estimé have often seen him as something

\footnotetext{
${ }^{70}$ Plummer, Haiti and the United States, p. 150.

${ }^{71}$ Alex Dupuy, Haiti in the World Economy (London, 1989), p. 151.
} 
of a traitor because they have held to a stringent interpretation of Marxism. For many, any move against communism was believed a move against the people. But considering that communism was more complex in Haiti, Estimé's policies towards it are complicated. The popular noiriste organizations, while essentially socialist, tended to characterize themselves as leftists specifically to avoid portrayal as red behind the western front of the cold war. Within Haiti, the Communist party was an elite organization and can be distinguished from its American counterpart in much the same way as the UNIA. This is not to posit Estimé as an undercover socialist; he was decidedly opposed to communism, but the implementation of the anti-communist law was mainly a measure against the official communist party.

Regardless of his opposition to communism, Estimé was seen as an obstacle to continued U.S. hegemony. Estimé intimated, in a conversation with American ambassador Orme Wilson, that the U.S. purchase of Haitian goods during the war had kept the island from economic disaster. Yet, he went on to state "the Haitian peasant benefited relatively little by this trade, as the imports which were received from the United States were distributed by the Lescot administration among its favorites, who made scandalous profits on them." ${ }^{, 72}$ Thus, Estimé aligned himself both with the peasants and against U.S. supported graft. The Haitian peasantry's recognition of and opposition to U.S. hegemony and government corruption informed Estimé's political stance. He, in fact, owed his office to the frustrations of the peasantry and was shrewd enough to give credence to their concerns in order to cement his position.

\footnotetext{
${ }^{72}$ Ambassador Wilson to Secretary of State, FRUS: 1946, p. 913.
} 
Yet Estimé's concern for the Haitian peasant may have been more than simply political maneuvering. "Estimé might well be considered a self-made member of the elite, but he was not born into it, and his accession to power was the political expression of new possibilities in Haitian life."73 Estimé was born in Verettes in the Artibonite Valley of modest parentage. He attended public schools and became a schoolteacher. He then secured the posts of Secretary of Education, Labor, and Agriculture under the Vincent administration. Thus, he had been close to both the underclass and the elite. ${ }^{74}$ Having seen Haiti from both sides of the fence helped to form his prejudices. "Estimé disliked white people and hated mulattoes with all the bitterness of a disadvantaged black. Yet at the same time he had such a weakness for mulatto women that the tan Oldsmobile he seduced them in was known as 'The Tomb of Virgins." 75 Estimé was of the underclass yet he favored the elite life. While it is impossible to know his inner thoughts, it stands to reason that Estimé may have felt some guilt about his station in life and therefore had a genuine concern for improving the lot of the peasant. Regardless of his impetus, the policy of the Estimé administration was focused on greater Haitian autonomy and better conditions for the Haitian peasantry through modernization. He believed that through modernization he could guide Haiti into the international market and that this would help to alleviate poverty.

\footnotetext{
${ }^{73}$ Sidney Mintz, Caribbean Transformations, p. 287.

${ }^{74}$ Nicholls, From Dessalines to Duvalier: p. 186.

${ }^{75}$ Abbott, Haiti: An Insider's History. p. 57.
} 
Estimé's primary opposition within Haiti was also concerned with improving the status of the Haitian peasantry. Emile St. Lot headed the Front Revolutionaire Haïtien, which had been instrumental in seeing to it that a black president was elected. After the election of 1946, St. Lot became active within MOP. This served as the primary base of more radical blacks. Though MOP's presidential candidate, Petrus Calixte, had expressed his support for Estimé, after the election the majority of MOP believed Estimé to be too moderate in his policies. Race had taken the position of primacy in the election of 1946, but class became the prime concern of many Haitians after the election. Now that the schism between mulatto and black had been ameliorated, the disparity between rich and poor needed to be dealt with. Where Estimé saw capitalism coupled with greater autonomy as the road to a better economy, St. Lot favored socialism. Estimé intimated to Ambassador Orme Wilson that "there exists a group of radical minded persons, among whom he mentioned Emile St. Lot, who call themselves leftists and wish to take drastic action against foreign capital." Estimé then related "that although, he too, could be called a revolutionary, and that although it is his intention to endeavor to free the Haitian peasant from his present condition of misery and squalor, he harbors absolutely no hostile feelings against American capital.",77 Thus, in the climate of the cold war Estimé had aligned himself with capitalism. However, Estimé believed that Haiti had to be free from U.S. hegemony to prosper. That is, Haiti desired to trade with and secure loans from the United States but did not intend to grant Americans free reign over the island in return.

\footnotetext{
${ }^{76}$ Wilson to Secretary of State, FRUS: 1946, p. 913.

${ }^{77}$ Ibid.
} 
When coupled with his black identity, he became as unpalatable to the United States as St. Lot and the leftists.

Estimé believed in maintaining trade with the United States while retaining economic sovereignty. The Estimé administration looked to Miami as a trading partner within the United States. In March of 1947, a busy month for the administration, Estimé organized an exposition of Haitian goods in Miami. The response of Frederick Hosea, a representative of the Mayor of Miami, was printed in Le Nouvelliste. Hosea claimed "this small showroom can be the starting point of a large international market where ourselves, other Americans, and our neighbors will be able to meet, to show our products, to learn reciprocal understanding, and carry out business." ${ }^{, 78}$ The volume of trade increased dramatically, but Haitian imports continued to exceed exports by a margin of one million dollars, a trend that had been fairly constant since $1938 .{ }^{79}$ Haiti was dealing in more products but continued to be a buyer rather than a seller in the international market.

Estimé's goal was to "build a modern country" and his plan for doing so was outlined in an article in Le Nouvelliste. According to the article, Estimé was working to "rapidly transform the country into the most advanced in the Antilles." ${ }^{, 0}$ In pursuing this goal, the Estimé administration built schools and increased wages for teachers and administrators. They also increased the minimum wage from thirty to seventy cents per

\footnotetext{
78 "Succes de l'exposition haïtienne a Miami," Le Nouvelliste, 22 March 1947.

${ }^{79}$ Statistical Abstract of Latin America, $10^{\text {th }}$ edition (L.A., 1966), p. 138-139.

${ }^{80}$ M.F. Dunbaugh, "Le nouveau President d'Haïti travaille a edifer un pays moderne," Le Nouvelliste. 14 October 1948.
} 
day. ${ }^{81}$ Thus, Estimé was responding to his prime constituents, workers and urban professionals. In addressing the concerns of the peasantry, Estimé built schools in small towns and rural areas and worked with the United Nations Educational, Scientific and Cultural Organization (UNESCO). Through UNESCO, the Estimé administration implemented irrigation and sanitation programs. Clearly Estimé was not averse to outside collaboration; he was simply opposed to U.S. hegemony.

In order to reify the policies of modernization and in response to popular demand, the Estimé administration went about drafting a new Constitution in 1946. The Constitution was the materialization of noirisme in legislation. It put strict limitations on foreign businesses, though less so on the tourist industry, and equated citizenship with blackness. It also protected freedom of the press, allowing an opposition voice within the elite. When they presented the proposed Constitution, both the U.S. and the Haitian elite protested it. Newspaper headlines read "The Constitution of 1946 is Inadmissible" and "We Denounce Article 12 of the Constitution." 82 Article 12 limited police powers and subordinated them more directly to the state. The United States saw the autonomy that the 1946 Constitution endorsed as defiant and many of the Haitian elite believed it financially suicidal. Some of the elite also considered it to be a maneuver to further divorce them from power. At the ground level, the programs that the Estimé administration pushed did not necessarily meet with enthusiasm from

\footnotetext{
${ }^{81}$ Alex Dupuy, Haiti in the World Economy: Class, Race, and Underdevelopment Since 1700) (London, 1989), p. 152.

${ }^{82}$ Granville Auguste, "La Constitution de 1946 est inadmissible," Le Nouvelliste. 1 August 1946 and Roger Charmant, "Autour de l'Article 12 de la constitution nous denoncons ," Le Nouvelliste. 4 March 1947 respectively.
} 
the peasantry who themselves sought a certain autonomy from the government. For instance, rural markets were considered a hindrance to modernization because they were believed to undermine the flow of capital into development programs. But for the Haitian peasantry they were a manifestation of economic self-sufficiency. Haitian rural culture was valued for its marketability to tourists. But for the Haitian peasantry it was intrinsically valuable and lost meaning when commodified. Thus, the Haitian peasantry was frequently at odds with the modernization that the Estimé administration believed to be the solution to Haiti's problems.

One contentious issue in the 1946 Constitution that all Haitians could back Estimé on was the Haitian claim to the island of Navassa, located thirty-two miles southwest of Haiti. This island was a major source of guano, which was used in fertilizer. Therefore, ownership of Navassa was important to the Haitian peasantry, who needed to fertilize their fields cheaply. Beyond the economic, Navassa was important symbolically in Haiti's resistance to imperialism. The United States division of Caribbean Affairs issued a protest to the Haitian claim to Navassa. However, the Haitian claim remained in the constitution. The United States did not seem to believe that Haiti would act on their claim and noted "this is a customary provision in previous Haitian Constitutions, and we were simply reserving our rights." 83 The United States had gained Navassa in the mid-nineteenth century and never actually left. The American government explained "since we are in actual possession of Navassa and the Haitian Government does not press its claim, the matter is usually quiescent." ${ }^{184}$

\footnotetext{
${ }^{83}$ Charles Hauch Memo, FRUS: 1946, p. 930.

${ }^{84}$ Policy Statement prepared in the Department of State, FRUS: 195I, p. 1463.
} 
Though the Haitian Government under Estimé attempted to "press its claim," the Island of Navassa remained in the possession of the United States.

Navassa is more than an island of putrid bird droppings. It is a part of the antiimperialist symbolic lexicon of Haiti. Alongside Toussaint l'Ouverture, Charlemagne Péralte, and the 'Steamroller' is Navassa, a small and stinking island that has at points been a literal battleground on which Americans and Haitians have fought. It is also a symbolic battleground on which the first independent black republic disputed the newly expanding United States' first imperial possession. Navassa has proven itself something of a dark secret in the correspondence of American officials and businessmen. Frank Crumbie took an interest in the island after hearing of it while working as a customs collector in Jeremie. Crumbie later became president of the Rockland Trust Company before he died in 1960. He had a defined interest in bizarre tales and collected newspaper clippings, dealing with everything from ectoplasm to leopard men, from various American newspapers. He also compiled various recipes for poison, apparently gleaned from a bokor he knew in Haiti. ${ }^{85}$ In February of 1953 he set about compiling information related to Navassa with the intent of writing an article about it. In a letter requesting information on the island he notes "I was told that I should not write about it during war times." ${ }^{90}$ On the letter in response to Crumbie's inquiries are the notes "To publish anything about Navassa you will have to get permission from the Commandant. US Coast Guard, Wash. D.C. ${ }^{, 87}$ As the

\footnotetext{
${ }^{85}$ Crumbie Papers. MS Group 14, boxes 1, 5, 6.

${ }^{80}$ Frank Crumbie to Office of the Commandant of the U.S. Coast Guard, 3 February 1953. Crumbie Papers.

${ }^{87}$ Adam Bishop to Frank Crumbie, 28 August 1953. Crumbie Papers.
} 
correspondence continues, a fairly sordid history directly connected to race and imperialism emerges. The United States staked a claim on Navassa in 1857 under the Guano Act. The Guano Act held that uninhabited and unclaimed territories on which guano could be mined were subject to U.S. annexation. Haiti, however, considered Navassa to be under Haitian sovereignty since 1804. In response to U.S. claims on the island, the Haitian government sent 2 war vessels to Navassa in 1858 . For the next 31 years the United States and Haiti continued to dispute Navassa. U.S. courts upheld U.S. claims and Haitians maintained Haitian claims so that the first U.S. colonial possession was such only in name.

American claims to Navassa became more tangible in 1889 . In that year eleven white superintendents and one hundred and thirty-seven black American laborers arrived at Navassa to begin mining guano. The workers were on fifteen month contracts and were to be paid upon returning to Baltimore after their contracts were up. Further, part of their wages was to be withheld as payment for the return passage. Working in the sun shoveling, hacking, and loading bird excrement was both laborious and unhealthy. The workers alleged abuse and overwork, and many in fact fell ill. The parallels to slavery under a new guise were there to be made. Whether the workers of Navassa made this connection or not, many of them organized in opposition to the whites and revolted in 1889 , the same year they arrived. They took up their axes and attacked their white supervisors, who were themselves armed with guns. In the battle, nine of the workers were killed and fifteen were injured. Several of the whites were injured as well, and at least one was killed. Crumbie characterizes the black workers as both "nigs" and "murderers," but has no such labels for the white supervisors. Indeed, 
the nine blacks killed are dismissed in his notes. However, he does explain that the remaining blacks involved were brought back to the United States, where they were tried and convicted. Their cases were appealed on the basis that Navassa was outside U.S. jurisdiction. The appeal went to the Supreme Court, illustrating the questionable nature of U.S. possession of Navassa. However, the Supreme Court upheld the convictions based upon the Guano Act of $1856 .^{88}$

Nine workers died in the 1889 uprising, and for nine more years guano mining operations continued on Navassa. In 1898 the guano mining operations were abandoned, but a few men were left there "to keep [the] island "occupied." ${ }^{89}$ U.S. mining operations were then replaced by German mining ventures. As the dominant power in Haiti prior to the U.S. occupation, German companies mined bauxite on Navassa. "The story is that a German company mined the bauxite using prisoners for the purpose. $" 90$ Whether the prisoners were German, Haitian, or affiliated with some other nationality is not mentioned. At any rate, they were treated in a manner similar to their African American predecessors of the 1890s. When not engaged in mining, the workers were housed in three cells and chained to a ringbolt fixed in the center of each room. The German tenure on Navassa was a fairly short one and the U.S. reasserted their claims to the island during the occupation. Throughout it all, Haiti and the United States had maintained their claims to Navassa. The occupation demonstrated that the United States was willing to claim resources and protect investments through force.

\footnotetext{
${ }^{88}$ Crumbie papers, MS Group 14, box 1 .

${ }^{89}$ Ibid.

${ }^{90}$ Bishop to Crumbie, Crumbie Papers.
} 
Thus, the United States was able to re-assert itself in Navassa and build a lighthouse through the aid of Cuban labor in 1916. The following year, Haitians described as "vandals" destroyed the living quarters attached to the lighthouse and were arrested. ${ }^{91}$ This would be the last documented case of physical resistance to U.S. encroachment on Navassa. From 1917-1946 Haitian accommodation of U.S. interests made Navassa an American possession to all but the general populace of Haiti. It was not until the 1946 Constitution that Navassa, the fetid microcosm of imperialism, re-appeared in U.S.Haitian relations.

The policies of the Estimé Administration, such as his refusal to abandon claims to Navassa, did little to endear Haiti to the United States Government. In preparing the new Constitution, the Estimé administration directly attempted to gain greater autonomy. The Constitution also made clear the connection between national identity and government policy. Articles six and thirteen of the proposed constitution targeted foreign business. Article six would limit foreign land holdings in Haiti and was believed to be an attack on large American businesses. Article thirteen read as follows:

Only native-born Haitians (i.e. 'Haitiens d'origine') may be engaged in retail business, manage such business and be engaged in such other commercial, industrial and professional activities as the law shall determine. A Haitian by origin is defined as any person of the black race, born of a father who himself is born a Haitian. Any person is also a Haitian by origin when of the black race, when not recognized by his father, but born of a mother who was Haitian by birth. ${ }^{92}$

Haitian identity here is clearly linked to blackness. Mulattos are not singled out in the definition, demonstrating the pervasiveness of blackness in Haitian identity after 1946.

\footnotetext{
${ }^{91}$ Ibid.

${ }^{92}$ Charge Mooers to Secretary of State, FRUS: 1946, p. 920.
} 
Another feature of this definition was that it favored Haitians to foreigners in business endeavors. The United States was "at a loss to understand why legislation apparently... highly detrimental to legitimate American financial investments in Haiti should be contemplated." 93 In response the United States thought "It might be well to remind the Haitian officials that if they and other responsible Haitians desire the continuance of mutually beneficial economic development by United States private enterprise, such enterprise should not be discouraged by discriminations against foreign investors, entrepreneurs and technicians."

Estimé validated U.S. fears of article six by dissolving the Standard Fruit Company. The Standard Fruit Company was a large American owned company that held contracts with peasant fruit-growers. In 1935 the Vincent administration, in concert with the United States, had granted an export monopoly to Standard Fruit. ${ }^{95}$ In 1947, Estimé refused to conclude a new agreement with the Standard Fruit Company. This caused a precipitous drop in banana exports, a trend that continued well after his presidency. ${ }^{96}$ He denied the new contract, based on the perception of Standard Fruit as a foreign leech and on his support for Haitian businesses. Haitians considered Standard Fruit another example of foreign powers profiting from the toil of the peasantry. Thus government support of a high profile company like Standard Fruit could be easily connected to the abuses of SHADA under the Lescot Administration. Estimé certainly wanted to avoid such a connection. His refusal to conclude a new agreement led to

\footnotetext{
93 Ibid, p. 917.

${ }^{94}$ Secretary of State to Tittmann, FRUS: 1946, p. 922.

${ }^{95}$ Hans Schmidt, The United States Occupation of Haiti, 1915-1934 (New Brunswick, NJ, 1971), p. 178.

${ }^{90}$ Edouard Francisque, La structure economique et socialle d'Haït (Port-au-Prince, 1986), p. 129.
} 
American "concern for the future of United States business." States perceived Estimé as a threat to its hegemony. Estimé implemented economic policies that favored Haitian autonomy and these ran counter to U.S. designs. The Estimé administration also made race an issue in relations between the United States and Haiti.

Race was negotiated in the drafting of the 1946 Constitution. The U.S. suggested the "elimination of the words 'of the black race,' pointing out that to retain this prerequisite would be a violation of the United Nations Charter, inasmuch as no distinction as to race should be incorporated into the Constitution." ${ }^{, 98}$ In response to the possibility of recognizing Creole as an official language entertained in the drafting of the constitution, the U.S. expressed the opinion that "Creole should not be recognized or permitted as a medium of expression in political assemblies." 99 Here the United States was actively suppressing the very "democracy" they claimed as their political and normative foundation. The language of the people of Haiti was not to be recognized in politics and governance. Through the medium of language, U.S. officials meant to deal with the Haitian elite exclusively and supported the chasm between rich and poor as it related to legislation. On the surface, the objection to the inclusion of race in the Haitian constitution seems admirable. Yet when coupled with the suggestion that Creole be barred from the political sphere, the dubious nature of U.S. objections becomes apparent. The motive behind these suggestions appears to be a

\footnotetext{
${ }^{97}$ Hauch Memo, FRUS: 1947, p. 735.

${ }^{98}$ Tittmann to Secretary of State, FRUS: 1946, p. 927.

${ }^{99}$ Ibid, p. 928.
} 
recognition of the re-emergence of noirisme in Haitian politics. Noirisme ran counter

to U.S. hegemony and could not be allowed expression in the Constitution of Haiti.

Thus, blackness in any form needed to be eliminated from the constitution. Further, to allow a constitutionally backed black identity in the Western Hemisphere could provide a locus of protest for pre-civil rights black Americans. But because essentially all Haitians now claimed a black identity, Creole also had to be attacked. The general population of Haiti was not allowed an official voice. Because Haitians insisted on claiming a black identity, the United States sought to ensure it remained under the control of the elite, where it could most easily be destroyed. The 1946 Constitution retained its racial component and was a victory for Estimé and his noiriste cabinet. However, it was not a victory that could be easily shared with the Haitian populace, as Creole was left outside the gates of the National Palace and the National Assembly.

The barring of Creole from the official bodies of Haiti fit the agenda of the Haitian elite. They had justified this exclusion because "Haitian Creole is not a written language." 100 In a nation where the vast majority of people were illiterate, using writing as a prerequisite for official recognition of a language was a means of silencing popular sentiment. The elitism of this practice is perhaps best illustrated in an anecdote appearing in the Saturday Evening Post. It begins with an affirmation of American racism:

Half a dozen miles off the north coast of Haiti...is a wild and steep-sloped island called Tortuga. As a seventeenth century buccaneers' stronghold a kind of violent prosperity touched it for a day. Now there is not a single white man on Tortuga. There are, however, some thousands of Negros - primitive folk who farm and fish, and want little

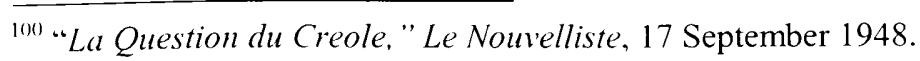


more than a pair of pants to wear, a burro to ride and a grass-thatched hut to keep off the rain. ${ }^{101}$

Here prosperity is equated with whiteness and primitive is synonymous with blackness.

After establishing this background the article tells of a missionary's efforts to convert the island's residents through the aid of bibles. The priest returns to visit Madame Aricia, a mambo who had apparently converted to Christianity, and the following ensues •

She invited him in happily, chattering about the satisfaction she had found in her new religion and the evidences she had observed of its truth. Then his eye, moving about the little room, fell upon the Bible. Its cover drooped oddly. Pére Najac rose and opened it. Many pages had been removed. 'Why have you mutilated your Book?' he asked quietly. 'Mutilated?' Madame Aricia asked, wide-eyed...Listen. You are a man of learning; you read your Bible and absorb its truths. But I cannot read. How then am I to absorb its truths into my mind and heart and body? I'll tell you. Each morning I tear a leaf from my Bible and eat it. ${ }^{102}$

The purpose of the anecdote is to illustrate the ignorance of the Haitian peasant, however, there is far more at work here. Madame Aricia holds the same respect for the Bible that Father Najac does. Both see it as a source of truth and power. The means of obtaining that power is where they differ. Elitism becomes manifest in these divergent approaches. Because her method does not fit a Western mold, Madame Aricia is portrayed as a fool. The damning proof of her "ignorance" is her inability to read. This dynamic was at work not only in the American perception of Haitians but also in the Haitian elite view of the masses.

${ }^{101}$ William Krauss, "Madame Aricia’s Bible," Saturday Evening Post, 10 October 1942.

102 Ibid. 
Madame Aricia's literal consumption of the Bible is interesting in light of the "trope of the Talking Book." 103 Henry Louis Gates, Jr. discerns this trope in eighteenth century slave narratives. It involved the perception of various African slaves and American Indians that books actually spoke to Europeans. This was not an unreasonable assumption for them to make in light of the fact that literacy was fairly alien even in Europe, where it is likely peasants held a similar view of books. The ability of books to exclude all but Europeans from their dialogue imparted their power and demonstrated the barring of marginalized groups such as slaves and peasants from this power. Europeans in fact defined humanity in terms of literacy and placed Africans at the lowest end of a racial hierarchy based on their general illiteracy. "So, while the Enlightenment is famous for establishing its existence upon man's ability to reason, it simultaneously used the absence and presence of reason to delimit and circumscribe the very humanity of the cultures and people of color which Europeans had been "discovering" since the Renaissance."104 Reason in this case was synonymous with literacy. Based on the inequality inherent to slavery, slaves were forced to contend with the charges of inferiority that their European master's leveled at them. Within this situation literacy was an avenue of resistance. "To read and write was to transgress this nebulous realm of liminality." 105

Americans inherited this equation of literacy with reason and by extension humanity, and it presented itself in their interactions with Haitians, both directly and in

\footnotetext{
${ }^{103}$ Henry Louis Gates, Jr., The Signifying Monkey: A Theory of Afro-American Literary Criticism (Oxford, 1988). This is title of chapter 4 and an important aspect of the book as a whole.

${ }^{104}$ Ibid., p. 130.

111 Ibid. p. 128.
} 
publications such as the Saturday Evening Post. The Haitian elite adopted this concept and were, in one sense, driven to literacy by faith in it to begin with. The peasantry also recognized the power of the word and attempted to receive it in various ways. For Madame Aricia, the method was to eat pages of the Bible everyday, expressing a respect for the power of the book in an animistic sense. More often, the course of Haitian peasants was to send their children to school in order to empower them. Alfred Métraux explains "it is the every peasant's ambition to send his children to school ... and he will make any sacrifice in order to be able to do so." 106 Métraux's gendering of the peasantry as male, while most likely dictated by the rules of French grammar, is interesting for two reasons. First, the money funding the education of peasant children was most often that of market women. Second, Americans and elite Haitians gendered the peasantry female invoking their secondary status in Haitian society. Madame Aricia is just one example of this practice, which is discussed more fully in Chapter V.

U.S. officials could rest assured that Creole would remain outside the realm of legislation, but the fear that an officially recognized affirmation of blackness could stimulate agitation in the United States had some merit. "Estimé's ascension to power provided an opportunity for new cooperation between Haitian and African American leaders, with the NAACP resurrecting its role as Haiti's publicity agent."107 The National Association for the Advancement of Colored People had initially acted as a "publicity agent" for Haiti during the occupation. Relations between African-

\footnotetext{
${ }^{106}$ Alfred Métraux quoted in Paul Farmer, Aids and Accusation: Haiti and the Geography of Blame (Berkeley, 1992) p. 34.

${ }^{107}$ Pamphile, Haitians and African-Americans. p. 150.
} 
Americans and Haitians tended to become tighter when Haiti asserted a black identity in opposition to U.S. hegemony. At such times Haiti proved a readily available rhetorical device for the aspirations of organizations such as the NAACP and the UNIA. On the Haitian side, the activities of African-Americans supplied the elite with ammunition for their ambitions. In numerous newspaper articles the Haitian elite take an active interest in the situation of black Americans. They are able to discern the color line and express a particular concern for blacks in the American South. They also impose a distinction between black and mulatto on the American context in order to attack it in the Haitian milieu. Invoking the primacy of noirisme in mid-twentieth century Haiti, Dieudonné Lubin notes "We do not need to redden our black American brothers (I refer in the term black to the lights as well)." ${ }^{\prime 108}$ That is, advancement was no longer the province of mulattos, and all African-Americans and Haitians could embrace blackness as a unifying factor. But the weakness of this new black identity is revealed in its goal, "My dream is that more Haitians will go to the United States and see the progress made by the black in contact with white civilization." 109 It was this faith in Western civilization that most profoundly separated the elite from the commoner in Haiti. In proclaiming blackness, the average Haitian was attacking the class schism that beleaguered Haiti. Yet for the elite, noirisme was a conduit to civilization and modernity and a useful tool for muting the division between rich and poor.

\footnotetext{
${ }^{108}$ Dieudonné Lubin, "Impressions de vovage le negre et son probleme aux Etats-Unis," Le Matin, 15 October 1947.

${ }^{109}$ Ibid.
} 
In response to Haitian contestation of U.S. hegemony during the Estimé administration, the American government withheld development loans. Haitians and African-Americans employed race in order to secure funds. Lucien Hibbert, Rector of the University of Haiti, "made reference to the loans the United States has made to European countries and stated that the Haitian public was sometimes unable to understand why the U.S. government were willing to advance money to other countries but not to Haiti." 110 Walter White, President of the NAACP, was far more explicit in linking the denial of loans to race and stated that it was "an example of 'Yanqui imperialism' and racial bigotry."111 For his assistance, White was awarded the Haitian order of Honor and Merit. This was an honor that Lescot had granted to President Eisenhower; the Estimé administration had a far different approach to foreign relations. Under Estimé, Haitian-NAACP collaboration was successful and "the Export-Import Bank granted Haiti $\$ 4$ million loan to finance construction of flood control, irrigation, and drainage works in the Artibonite Valley." 112 Thus, the Estimé government in concert with the NAACP was able to use race to obtain economic concessions. The U.S. decided to grant assistance to Haiti because of "the happy effect assistance to a Negro republic would have on the colored races everywhere."113 The United States Government was willing to aid Haiti in order to divert the ire of blacks within the

\footnotetext{
${ }^{110}$ Memorandum of conversation between Charles Hauch, division of Caribbean affairs and Lucien Hibbert, FRUS: 1947, p. 732.

111 Pamphile, Haitians and African-Americans. p. 152.

112 Ibid.

${ }^{113}$ Hauch Memo, FRUS: 1946, p. 949.
} 
United States. The Estimé administration had found alliance with American blacks more fruitful than accommodation to U.S. interests.

Race was of great importance in the U.S. assessment of the Estimé administration. The Estimé cabinet was primarily composed of noiristes. It included Dr. Jean PriceMars as Minister of Foreign Affairs. ${ }^{114}$ Francois Duvalier was Secretary of Labor and Public Health. ${ }^{15}$ Daniel Fignolé served a partial term as Minister of Education. The cabinet also included Gaston Margron as Minister of Finance. Margron was not a noiriste and was believed by the United States to be "perhaps the only Haitian...considered to have the capacity to grasp fully the operation of Haitian finances." 116 The United States claimed that Margron "[knew] that once the complete control of Haitian finances [was] returned to Haiti ... his old job in the National Bank now being held open for him, would vanish into thin air."117 Employing the threat of economic ruin, the United States hoped to use Margron's position as minister of finance to strengthen their hold on Haiti. Because Margron feared the possibility of losing his elite status, which had material expression in his National Bank job, he could be counted upon to aid U.S. interests. Estimé however did not fear autonomy and believed that Haiti would prosper without the United States on its back.

Estimé's attempts to gain Haitian autonomy earned him the scorn of the U.S. government. In a discussion with Ambassador Tittmann, he stated bluntly "sometimes I ask myself if it is the policy to keep this country as it is, and that you are carrying out

\footnotetext{
${ }^{114}$ Wilson to Secretary of State, FRUS: 1947, p. 914.

115 Nicholls, From Dessalines to Duvalier. p.168.

${ }^{110}$ Tittmann to Secretary of State, FRUS: 1946, p. 944.

$11^{-}$Ibid.
} 
that policy."118 Estimé elicited U.S. imperialism and went on to note "that it wasn't their fault that Haiti was in the Western Hemisphere."119 Tittmann characterized Estimé as "irritable, hostile, emotional, and inclined to blame the United States and the Bank for his inability to make a complete change overnight." ${ }^{20}$ Such a characterization was reminiscent of the depiction of Haitians as "mad from the sight of blood."121 Estimé's resistance to U.S. hegemony was subsumed under mental and emotional traits ascribed to him by a U.S. official. The U.S. suggestion for the revision of a 1941 executive agreement required "that a competent Haitian be appointed to head the Haitian financial system."122 Throughout U.S. government documents from 194650, "Haitian" was qualified with the term "competent." The clear implication was that Haitians in general were incompetent. Coupled with the fact that Haiti was perceived as the "Negro republic" the characteristic of incompetence would seem to be linked to racial constructs.

The extension of "Haitian incompetence" was "benevolent hegemony." If Haitians were incompetent, except in the case of accommodationists like Gaston Margron, then the United States should direct investment and policy on the island. The Haitian perspective was quite different. Philippe Charles Haitian Ambassador to the U.S. stated "one cannot question the good intentions of the United States, but every time the United States has tried to help us, they have increased our confusion and

\footnotetext{
118 Ibid, p. 937.

119 Ibid

${ }^{120}$ Ibid.

${ }^{121}$ R.B. Davis, FRUS: 1916 , p. 318.

122 Tittmann to Secretary of State, FRUS: 1946, p. 943.
} 
poverty instead of lessening it." 123 In other words, Haitians should be in control of investment and governance in their nation. From the Haitian standpoint Americans were interested in profit and not development, while from the U.S. vantage point Haitians were incapable of productive self-government.

An example of the divergent perspectives of Haitians and Americans is how each viewed the activities of the Societe Haïtiane Americaine Development Agricole (SHADA). SHADA was controlled by the United States and directed investment in agricultural programs nationally. It was most active during the presidency of Lescot, from 1941-46, but continued to operate under Estimé. Estimé sought to gain control of SHADA and put it towards programs like the irrigation of the Artibonite, in which he was successful. SHADA was a political demon based on its association with imperialism and the graft of the Lescot administration. U.S. Director of Caribbean Affairs, Charles Hauch, noted that Haitians made the "usual Haitian claim that SHADA had expropriated lands, destroyed crops, cut down trees, and not compensated the peasants for their losses." ${ }^{124}$ Haitians perceived SHADA to be a wave of transmogrification that converted land into intangible capital. Under Lescot, valuable cropland was used for sisal, rubber and other exports, the profits of which were distributed within the government and never reached the general population. Nonetheless, the U.S. government perceived SHADA's activities to be "a substantial contribution to the improvement of the Haitian economy." "25 Therefore they expected

\footnotetext{
123 Circular Airgram, FRUS: 1947, p. 727.

${ }^{124}$ Hauch Memo, FRUS: 1946, p. 951.

${ }^{125}$ Acting Secretary of State to Haitian Special Mission, FRLIS: 1947. p. 725.
} 
the Estimé administration to pay for the debts relative to SHADA that had been incurred during Lescot's tenure in office.

For the Haitian peasantry "development" was often an impediment rather than a catalyst to progress. Alex Dupuy explains that SHADA

...acquired land in various regions of the country for a total of 133,400 hectares, or 21.5 percent of the total cultivated area of Haiti. In the process of establishing these plantations, large numbers of peasants were evicted from their land and their crops destroyed. Some peasants were given no more than 48 hours to leave their land, paid $\$ 25$ per carreau planted, or a mere $\$ 5$ in other cases. Tenant farmers received a compensation of $\$ 10$. By July 1943 , the SHADA employed a total of 64,400 workers on its various plantations...the workers received a wage of 30 cents per day for a tenhour day. ${ }^{126}$

What U.S. officials claimed to be a substantial improvement to the Haitian economy was in reality an unabashed attack on an entire way of life. To the Haitian peasant, land is the crux of society. James Leyburn notes that "land is to the peasant both home and living; his household is dependent almost solely upon the product of its own labor."127 Beyond being the source of income and sustenance it is the residence of ancestors and lwa. "The lwa, and peoples' relations with them, stand (to borrow a locally significant metaphor) at the very crossroads of Haitian social and cultural life." ${ }^{28}$ Lwa are noncorporeal yet anthropomorphic spirits who function as gods and exist within the physical and temporal world. ${ }^{129}$ They serve a multitude of functions from aiding in

\footnotetext{
${ }^{126}$ Alex Dupuy, Haiti in the World Economy (London, 1989), p. 145.

127 James Leyburn, The Haitian People (New Haven, CT, 1941) p. 74. Leyburn generally employs "he" and "his" to describe the peasantry in general. However, in discussing field activity these terms are gender specific as men were involved in cultivation and women in commerce (a point which he is careful to note).

${ }^{128}$ Ira Lowenthal, “'Marriage is 20, Children are 21:' the Cultural Construction of Conjugality and the Family in Rural Haiti." PhD Dissertation, Department of Anthropology, (Johns Hopkins University, 1987) p. 212.

${ }^{129}$ Ibid., 213.
} 
harvests to settling disputes. As noted, these lwa are connected to the land. "Over and above the ceremonial importance of particular sites, however, land has always been -and undeniably remains --the sine qua non of personal freedom and individual autonomy ... from its very inception in the pre-Revolutionary peasant adaptations of freedmen and maroons." 130 Since the revolution "the average Haitian preferred to be his own master, working only when he wished, and particularly working only for himself and his family." ${ }^{.131}$ SHADA forced nearly a quarter of the Haitian peasantry to trade their independence, however economically fragile, for wage labor under the direction of the elite in conjunction with foreigners.

The source of this oppression was fairly clear to the peasantry. Paul Farmer has described the manner in which AIDS, during the Duvalier years and beyond, was perceived as "an illness that could be 'sent' on an enemy.", 32 The dynamic informing this perception had its "origins in the colonial epoch, and the lineage of these ideas may be studied in the historical record." ${ }^{, 133}$ Under Lescot, AIDS was not the scourge of the peasantry, SHADA was. Through SHADA, the elite were able to literally transform the central feature of peasant life, land, into worthless rubber and sisal. The peasantry could not eat either product and were barred from the power to trade them for more useful things. SHADA was simply another expression of the disenfranchisement of the peasantry, who were subjected to the desires of the distant rulers of Washington D.C.

\footnotetext{
130) Ibid., 253-254.

131 James Leyburn. The Haitian People, p. 65.

${ }_{132}$ Paul Farmer, Aids and Accusation: Haiti and the Geography of Blame. p. 257

${ }^{133} \mathrm{Ibid}$.
} 
and Port-au-Prince. As the peasants perceived it, through SHADA the moun lavil (city people) sent a flood of destruction upon ancestral lands.

The United States Government and the Haitian elite ignored the fact that peasant proprietorship had long been the heart of Haitian conceptions of freedom. During the occupation "the locally oriented subsistence agriculture cherished by Haitian peasants registered with American progressives as little more than a sign of backwardness."134 Mary Renda explains the American view of peasant proprietorship during the occupation as follows:

Its value as an optimal economic arrangement for a people at odds with international capitalism was inadmissible within a racial and class framework that denied black peasants the ability to determine their own interest. The very notion of developmentalism ... presupposed that there was but one path toward progress and light. And this assumption - that the path followed by Western European countries and by the United States was the proper path for all - was, among other things, a racial assumption. In this sense, racial hierarchy under girded liberal development at every point. $^{135}$

This attitude continued to characterize the American perspective during Estimé's presidency. Yet it was not only Americans who considered the Haitian peasant to be "backwards." The Haitian elite shared this perspective as well. For Americans, the solution was to help Haitians overcome their "racial handicap" and embrace capitalism. Under Lescot, the peasantry was not so much a problem as a resource, which could be tapped through "development" projects like SHADA. Under Estimé, the solution to the "peasant problem" was modernization. This is not to argue that the Haitian peasant lived a romantic existence close to the land and ancestral spirits. To the contrary,

\footnotetext{
${ }^{134}$ Mary Renda, Taking Haiti: Military Occupation and the Culture of U.S. Imperialism, 1915-1940 (Chapel Hill, NC, 2001), p. 114.

135 Ibid.
} 
Haitians faced poverty as a very real difficulty. However, the modernization promoted by Estimé did more to act upon peasants than to empower them. To add insult to injury, programs like SHADA, though a manifestation of U.S. hegemony and not an Estimé modernization program, disconnected peasants from land, which was of greater value in every aspect of life than a menial job could ever be. Further, SHADA entailed oppression for a people who equated subsistence agriculture with freedom. ${ }^{130}$

The fact that they were expected to foot the bill for SHADA programs under Lescot outraged Haitians. In February of 1946 workers and peasants demonstrated in front of the SHADA building in Port-au-Prince. Le Nouvelliste warned of the importance that "the leaders of SHADA understand the direction and spirit of the revolution of January $7^{\text {th }}$ and do right through arbitration of the demands of the employees and workmen of the forest." 137 Their demands were for the cancellation of SHADA debt because they felt "Haitians did not have a voice in the handling of the funds." ${ }^{38}$ The SHADA debt was six million dollars and from the Haitian point of view resulted from the bad economic policy of the United States alongside the Lescot administration. ${ }^{139}$ Where American officials believed Haitians to be incompetent, Haitians considered the United States out of touch with their needs as evidenced in programs like SHADA. Further, Haitians felt they were being charged six million dollars for giving up their land and freedom to Americans.

\footnotetext{
${ }^{136}$ For an examination of a similar situation in post-"emancipation" Jamaica see Thomas Holt, The Problem of Freedom: Race, Labor, and Politics in Jamaica and Britain. 1832-1938 (Baltimore, MD, 1992). 137 "Manifestation contre Holdrige devant les Bureaux de la SHADA, " Le Nouvelliste, 1 Februaury 1946. ${ }_{138}$ Ibid.

${ }^{139}$ Clement Celestin "Mauvaise politique economique," Le Nouvelliste, 28 Februaury 1946.
} 
"Haitian incompetence" seemed in actuality to be pragmatism. The United States was concerned with converting Haitian goods into profit. Haitians were concerned with bettering their living conditions. Estimé's attempt to secure funds for a slum-clearing project further illustrates the different objectives of Haitians and Americans. The Estimé administration sought a loan for a slum clearing and housing project in order to stimulate tourism and respond to the demands of the urban poor for better living conditions. Yet the U.S. controlled Export-Import Bank responded with the following:

The bank recognizes that such projects are desirable and often essential to the health and welfare of the people of all countries; however, they do not directly enhance the productive capacity of the country and thereby create the means by which there can be produced the additional goods out of which a loan must be repaid. ${ }^{140}$

In order to secure the loan, the Haitian Government played on cold war fears. Dr, Rigaud, former Minister of Commerce and Agriculture, "emphasized the thirty to forty thousand intellectuals, who, he said, were young men of good education who could not find positions in Haiti and hence were potential political organizers and agitators." The Estimé administration was thereby able to secure the loan and proceed with the slum clearance. The slum-clearance provided employment, but rather than provide the urban poor with housing, the area was used for the International exposition. This stimulated tourism and created more temporary jobs. ${ }^{142}$

\footnotetext{
140) Secretary of State to Haitian Embassy, FRUS: 1948, p. 597.

${ }^{141}$ Hauch Memo, FRUS: 1946, p. 947.

${ }^{142}$ Abbott, Haiti: An Insider's History. p. 56.
} 


\section{Ap Vann Ayisyen Yo}

Tourism was central to the Estimé administration. It was the means by which the elite of Haiti could fund modernization and capitalize on "Le Vogue Negre." root of Le Vogue Negre was a prurient fascination with the "primitive" and "mysterious." In this sense racism was vital to tourism because it was the very "otherness" of the common Haitian that made them a marketable resource. From the American perspective blackness was a mark of inferior evolution and a badge of savagery. Further, 87.5 percent of the Haitian population was rural, making them all the more intriguingly "backward" to the American tourist. ${ }^{14 t}$ Indeed Haiti met all the prerequisites of American superstition making it an enticing tourist stop. For these same reasons Americans sought to distance themselves from Haitians when visiting. An English language article in Cahiers d'Haïti states excitedly that "Haiti has a Yacht Club" and goes on to note "safe fresh water is to be made available, diesel oil and gasoline, groceries and all necessary provisions can be delivered at the dock." Noticeably, Haitian water was assumed tainted and the prospect of going into a market to secure provisions was unpalatable. This was likely due to the assumed volatility of the Haitian people. "The only reason that hundreds of Americans cruising yachts have not visited Haiti before the war was that the Republic had no Yacht Club; no place

\footnotetext{
${ }^{143}$ Brenda Gayle Plummer, Haiti and the United States. p. 130.

${ }^{144}$ Statistical abstract of Latin America, $10^{\text {th }}$ edition (Los Angeles, 1966), p.14. The statistic is for the year 1950 and it is safe to assume that prior to that year an even greater percentage of the Haitian population was rural.

${ }_{1+5}$ Commodore Horace Ashton, "Haiti has a Yacht Club" Cahiers d'Haïti, April 1945, p. 39.
} 
where a visiting yacht could anchor in safety." to visit Haiti without a yacht club present. Invoking the racism integral to Haitian tourism, the same article explains "As one of the two Negro republics of the world, it has long been a land overflowing with appeal for the traveller no matter what his interest." ${ }^{147}$ In the 1930s and 1940s the interest of American travelers was in a Haitian culture sanitized, dislocated, and appropriated by the Haitian government.

The Estimé administration recognized Haiti's appeal to tourists and sought to use it to secure the money that would fund modernization. Haitian newspapers stressed the natural beauty of the island as the real catalyst to tourism. "The landscapes of Haiti are picturesque and combine all the astonishing color of New Mexico and Colorado with the luxuriance of the tropics."148 From the Haitian point of view the American West was exotic and is invoked here as part of the draw of Haiti. The appeal of exoticism is recognized but articulated in reference to the United States.

In order to reap the profits of "Le vogue Negre" the Estimé administration funded hotels and expositions. They courted Pan American Airways and Hilton Hotels and considered the possibility of a casino in Port-au-Prince. But the centerpiece of Estimé's tourism agenda was the International Exposition of 1949. As such, the newspapers followed the construction of the exposition grounds closely. Le Matin devoted an entire section of its August $17^{\text {th }}$ edition to the urban renewal projects of Estimé. In

\footnotetext{
140 Ibid.

${ }^{147}$ Ibid.

148 "La culture francaise grandit en Haiti la Republique est un vrai charme pour les touristes," Le Matin, 30/31 March 1947.
} 
laborious detail all of the road paving and maintenance projects of the island were catalogued, complete with commentary. The attention given the exposition was based on the belief that it would allow Haiti to "realize its personal destiny and contribute to the prosperity of the Haitian community." 49 Tourism and modernization were seen as inseparable, even as the exotic appeal of Haiti was superficially opposed to modernity.

The commodification of Haitian culture placed the peasantry in an awkward position. Under Lescot Vodou and the songs and dances associated with it had been simultaneously suppressed and appropriated by the Haitian government. A legal distinction was made between folklore and superstition, allowing the elite to mold an idealized popular culture palatable to outsiders. "In a sense, by legalizing what had never before been expressly prohibited, the law annexed the figure of popular dance to the state and laid a juridical groundwork for the subsequent promotion of this construct as an official national sign." ${ }^{150}$ Haitian cultural expressions less easily consumed or perceived as a threat could be labeled superstition and repressed in response. The elite needed the peasantry in order to legitimize their hollow versions of popular culture. Yet the elite had long distrusted the peasantry and held themselves aloof from the common man. Hence, the Haitian peasant was both the lifeblood and the bane of this reconstituted Haitian folklore.

Under Estimé the distinction between folklore and superstition was less defined but the exploitation of the peasantry for foreign consumption remained central to

\footnotetext{
149 "La politique des routes," Le Matin, 17 August 1948.

${ }^{151 "}$ Kate Ramsey, "Without One Ritual Note: Folklore Performance and the Haitian State, 1935-1946," Radical History Review'. 84 fall 2002, p. 14.
} 
tourism. Estimé strove to make tourism the economic base of Haiti. In this sense he picked up where Lescot had left off. But by the late 1940s the yacht club was no longer a prerequisite for catalyzing tourism. By this point Haitian tourism was secure and the Estimé administration strove to maintain it as such. The draw of Haiti remained the same, an advertisement in English running in Le Matin throughout 1948 showcased a disheveled and dejected Haitian boy staring at the ground and stated:

Amazing show-Latest Vodoo dances. Haitian folklore scenery. Songs, drums, vodoo creations. Exciting, startling show! Do not fail to go to $<<$ Wodoo Club $>>$ See a 6 year old child petting, Kissing, playing with a rattle snake, Wonderful.- Typical Haitian numbers. Unexcelled enjoyment. Something worthy of your time. Bring all your friends at the VODOO CLUB open on Wednesday and Saturday Dancing with a $<<$ Super-Jazz $>>$. ${ }^{151}$

Leaving the sexual undertones of the advertisement aside, the appeals to elitism and racism are clear. The child exploited by this advertisement is a ready example of the liminal position of the peasantry, which was most profound in the meeting of religion and tourism under the gaze of the government.

Maya Deren presents an example of the divergent pulls of tradition and performance. She describes the participation of a ougan named Titon in the International Exposition of 1949, which was the culmination of Estimé's tourism campaign.

During the period of the Haitian International Exposition, an effort was made to present Voudoun as a folklore attraction for tourists: to stage dances and rituals, and even simulate possession by deities. Titon's ability as a dancer and singer made him an obvious choice for this entertainment. Yet from the beginning, his Ghede opposed his participation. Titon himself could not understand the opposition, and in a desperate desire to earn the needed money, accepted the employment. ${ }^{152}$

\footnotetext{
151 "Vodoo Club in Carefour," Le Matin, 24 March 1948.

152 Maya Deren, Divine Horsemen: Voodoo Gods of Haiti (New York, 1970), p. 79.
} 
Titon gave only one performance because his left eye closed up and he took it as a signal to withdraw from the exposition. Deren claims "Titon himself had neither the sophistication nor the experience to evaluate the presentation precisely." 153 Indeed Deren is quite skeptical of Titon's mental capacity. Yet his position as a ougan and his apparent discomfort with presenting aspects of the religion he held sacred does not seem to require ignorance on his part. In fact, Titon's guilt in making a caricature of his beliefs in order to bring in vital funds is evidence of a fairly lucid understanding of his situation.

From a strictly economic standpoint Titon's situation was preferable to that of most other peasants disconnected from the benefits noirisme had promised. In giving the peasantry a voice, albeit one loosely translated into French and censored, the Estimé administration had improved upon previous administrations, at least at the symbolic level. For this reason much of the peasantry was willing to put faith in Estimé and he is remembered without the same disdain accorded rulers such as Lescot. However, the distance between city and country remained far more than that of the rutted roads and footpaths that connected them. One measure of the dislocation between urban and rural Haiti was technology. Estimé's "tomb of the virgins" was a rarity. Cars were the possessions of elite Haitians and foreigners staying on the island. Even in the late 1950 s when the automobile had become relatively commonplace in the "modern"

${ }^{153}$ Ibid., p. 80. 
world, there were only about nine thousand vehicles in all of Haiti, which had a population exceeding three million. ${ }^{154}$

In 1946 one Haitian car, in particular, traversed the boundary between urban and rural, modern and traditional. Among the people of Haiti a story had been circulating that a "tiger car" was driving through rural areas and kidnapping children. Late on a Saturday evening in September of that year people near Leogane noticed a youth disappear in the dim lights of an automobile. At the same moment a passer-by upset a dog, which kicked off a string of barks and howls as all the dogs of the area joined in the distress. The people of the area believed that "l'auto-tigre" or more appropriately "machin tig la" had kidnapped a local child. Accordingly a group of at least thirty people organized to retrieve it, the gender of the child is not disclosed. Because Leogane was relatively urban in contrast to other areas of Haiti, it is difficult to consider this group peasants, though they may have been. In any case they were not members of the elite and their story imparts something of the overall perception of the underclass, being workers and peasants, to the process of modernization. They made their way to a Port-au-Prince hotel where they believed the tiger car to reside. The car thought to be the auto-tigre belonged to the wife of a Max Bouchereau. The group demanded the whereabouts of the kidnapped child and when the Bouchereaus claimed ignorance of the incident they were attacked. They managed to escape after receiving severe injuries from rocks and machetes. ${ }^{155}$

\footnotetext{
${ }^{154}$ Statistical Abstract of Latin America, $9^{\text {th }}$ edition (L.A., 1965), p. 108. No information is available prior to 1958 but it is safe to assume that in the 1940s there were far less than 9,000 cars in Haiti. 155 "L'Affaire Bouchereau: n'a aucun caractere mysterieux," Le Nouvelliste, 2 September 1946, p. 1,4 .
} 
The violent reaction of the underclass to the "tiger car" offers a glimpse into their perspective of modernity. The legend of "machin tig la" posits modernity as literally consuming the underclass. Modernity is represented in the form of a car, an apt symbol for the concept indeed. The car is characterized as an aggressive and foreign beast eliciting something of the lower class conception of the elite. The goal of the car is to kidnap peasants and thereby divorce them from their land. The fact that the lower classes knew to find the "tiger car" within Port-au-Prince suggests that they were cognizant of the urbanization which modernity entailed. Here again, the moun lavil yo were sending afflictions to the people.

The "tiger car" is a particularly interesting example of a sent problem. Driving was perhaps even more elusive to the peasantry than literacy. It is unclear whether the peasantry viewed the Bouchereaus as having actually driven the "tiger car" or simply having sent it out to kidnap the child independently. It is however certain that the underclass did not drive and would likely have associated the process with wanga, magic. Once again, value judgments need to be assessed, that the underclass perceived of processes such as modernization in terms of wanga does not condemn them as ignorant but illustrates their lexicon for the events that had a direct resonance to their lives. Where SHADA was a means for moun lavil to consume the land of peasants, the "tiger car" was a way for them to consume the peasantry itself. However, the lower classes are not complaisant in this development and take up arms to destroy the "tiger car" and preserve their way of life.

The initial report of what became known as "l'affaire Bouchereau" considered it an instance of class antagonism. "The gullibility of the simple minded to the marvelous 
tale of the auto-tigre, the overexcitement of the proletariat due to an unhealthy propaganda of division, are the elements that constitute l'affaire Bouchereau." 156 In depicting the Haitian people as gullible and excitable, the Haitian elite drew upon the very prejudices leveled against them by American officials. They also expressed cold war concerns in placing socialism/communism at the root of the incident. Here they inverted false consciousness and claimed that the ignorance of the peasantry had left them open to the self-destructive propaganda of socialism, as espoused by Emile St. Lot. Having noted this, the article takes a shot at St. Lot by claiming that based upon class divisions he could just as easily have been the target of the attack (since he was now a member of the elite). By the $30^{\text {th }}$ of September Le Nouvelliste had backed off its St. Lot conspiracy theory and offered two new explanations for the auto-tigre incident. The first hypothesis was that the government had played on peasant fears in order to scare them into lowering prices for their goods and abandoning "black market" activities. The other hypothesis held that the incident was all a practical joke and that the kidnapped child and the wanderer who had startled the dogs were the same person. ${ }^{157}$ Neither of the theories could be substantiated and the articles relative to "l'affaire Bouchereau" served primarily to criticize the peasantry and the government.

The fact that a car should find expression in Haitian folklore as a hostile creature is understandable in the larger social matrix of mid-twentieth century Haiti. The successes of the Estimé administration were measured largely in terms of modernization. But the road to "civilization" was often more imposing than inviting to

\footnotetext{
156 Ibid., p. 4.

157 "L'auto-tigre," Le Nouvelliste, 30 September 1946. p. 1.
} 
the Haitian peasant. "Yesterday, in the afternoon, at the intersection of Fonts-Forts and Grand'Rue, a peasant woman had her right leg fractured by police motorcycle No. 15 . The victim was taken to the General Hospital." ${ }^{\text {158 }}$ In this case the police and roads characteristic of modernity were to the disadvantage of the peasantry. The Hospital was treating injuries brought about by its birthright, "modern civilization." This is not to be wholly cynical about the concepts of modernity and civilization but rather to illustrate the reasons that the peasantry did not always embrace them. The Haitian elite, however, was more fond of reproving the peasantry than empathizing with them. An article titled "the problem of the rural markets" blamed the peasantry for the economic distress of Leogane and Grand-Goave. ${ }^{159}$ The peasantry established "black markets" where goods were sold or traded and the funds generated remained within the rural communities. Like Estimé the peasantry was concerned with autonomy and in pursuit of this goal they had organized rural markets in Leogane and Grand-Goave. In doing so they were considered to be undercutting the urban markets and foiling the progress of the Haitian government. They were condemned with "the rural markets...constitute a serious handicap to the evolution of our countrymen and of our cities."160 The very Haitians portrayed as incompetent and backwards in U.S. government documents were directing the same charges towards the peasantry. Estimé's response was to send out special agents in order to "secure wholesale and retail prices set by the Government."161 In practice these agents "became an organized shake down squad peddling their

\footnotetext{
158 "Une paysanne victime d'accident," Le Nouvelliste, 9 January 1947. p. 1.

159 "Le probleme des marches ruraux," Le Nouvelliste. 27 September 1947. p. 1.

${ }^{160}$ Ibid.

${ }^{101}$ Lyonel Paquin, The Haitians: Class and Color Politics (New York, 1983) p. 104.
} 
protection, and bleeding the merchants."162 Essentially the people of Leogane and Grand-Goave were being abused for taking economics into their own hands.

The hands taking hold of economics in this case were feminine. This is because in Haiti market activity is the province of women. Beyond this, market women are a symbol of the peasantry. Postage stamps circulating in Haiti under the Lescot administration illustrate this. These stamps were financed by the united nations war relief fund and featured a market woman clothed in brilliant white standing in front of a basket overflowing with food of all descriptions and reaching, arms outstretched, to a group of war ravaged Europeans. ${ }^{163}$ The Haitian peasantry was gendered as female and glorified as a provider. The peasantry did not see themselves as providers in the war effort but as victims of Lescot's economic policies. The women appropriated as symbols had little access to power particularly in the urban context. The place where women exercised the most power was in rural markets. They arrived at this position as a result of men's dominance in cultivation. After 1804 "the gradual accumulation of land by an expanding peasantry" provided "land enough to free women from cultivation but not land enough to produce a yield sufficiently large to make it profitable for the peasant cultivator to go regularly to market himself."164 Whether this freedom from cultivation was an expression of female empowerment or submission is debatable. The result was that women gained control of internal commerce. Under

\footnotetext{
102 Ibid.

103 "Presse de Son Excellence le President de la Republique People Haïtien, le 15 Aout 1944 a l'Occasion de la Mise en ante du Timbre Special Emis au Profit de la Section de Secours aux Nations. Unies du National War Fund," Cahiers d'Haiti, August 1944.

${ }^{164}$ Sidney Mintz, "Men, Women, and Trade," Comparative Studies in Society and History. v. 13, no. 3, July 1971. p. 256.
} 
their direction market activities became profitable such that in some cases "a Haitian market woman can, by a combination of hard work, commercial acumen and good fortune, increase her capital holdings from a few cents to a few thousand dollars." 105 Women have retained control of market activities because "Young girls-and, often, even babies- are taken along on trading trips, and girls always learn how to trade from their mothers, other female relatives, or foster mothers." 166 While men control production and external trade, they have "no recognized claim" to the profits of market women. ${ }^{167}$ In the same way that land ownership allowed the peasantry a certain degree of freedom from the state, marketing offered women some autonomy in a male dominated society. As noted, the rural markets were under attack from the elite, who considered them obstacles to modernization endorsed by Estimé. Hence the "problem of the rural markets" was also a problem of women and from the peasant perspective not a problem at all.

Peasant women appear in Haitian documents primarily when they are being run over by police motorcycles or criticized for market activity. Elite women when not at the window of Estimé's infamous car, are also accorded little in the way of acknowledgment. They played a role subordinate to men and were rewarded through rhetoric praising their importance to the men who excluded them from full participation in the governance of the nation. Within the revolution of 1946 they saw an opportunity to agitate for greater women's rights. A letter from the Ligue Feminine d'Action

\footnotetext{
$165 \mathrm{Ibid}$.

160 Ibid.

16: Ibid.
} 
Sociale (LFAS) to the military junta was printed in an edition of Le Nouvelliste. Mme. Auguste Garoute, President of LFAS, addressed the junta with "the LFAS has full confidence in your spirit of justice and impartiality so that satisfaction is now given to the call of the Haitian woman, which is to participate in the upcoming legislative elections, in the full role which she intends to play there." 168 It is notable that the LFAS took a tone of deference in recognition that it is men who will ultimately decide whether or not they are allowed to vote. These men disregarded the confidence the LFAS had placed in them and women were not granted the vote until 1950.

The manner in which the peasantry was gendered female and symbolized in the form of the market woman invokes power relations within Haiti. Women, even elite women, were second-class citizens. They were denied the vote for the majority of Haitian history. They were granted marketing rights because these were initially considered of little consequence. They were expected to accept male infidelity yet be devoted in their own relationships. Hence women serve as a fitting symbol of the peasantry. This is because like women, peasants were expected to turn the other cheek when they were slapped. But the peasantry was also symbolically comparable to women in that it was women who gave birth and it was women who nursed children. It was the ancestors of the peasantry who created Haiti as an independent republic and it was the peasantry who nurtured Haiti in the face of an abusive elite.

The desires of the peasantry were not so ominous as the United States and Haitian elite believed them to be. In certain ways, the Haitian peasantry was willing to accept modernity on their own terms. The destination of the funds of market women is a

${ }^{168}$ Le Nouvelliste, 17 January 1946. 
telling example of the peasant perspective on modernity. "Market women use their profits in domestic upkeep, for education of their children, [and] for vodoun ceremonial payments." ${ }^{169}$ Family, education, and religion are the primary concerns of the peasantry. Land is both the source of their maintenance and the locus of their existence. Education is a product of modernity that the peasantry is willing to engage and do so in a manner similar to symbolic appropriation.

Paul Farmer describes this dynamic among the descendants of mid-twentieth century Haiti. In keeping with Estimé's "modernization," while at the same time returning to a complaisant subservience to American capital, President Paul Magloire funded a dam in the Artibonite Valley. The purpose of the dam was to provide electricity for Port-au-Prince, and its construction illustrates the conflict between modernity/urbanism and peasant proprietorship. The damming of the Artibonite River flooded a rural Haitian village, which Farmer calls Petit-fond. The inhabitants were selectively reimbursed and considered monetary concessions to coincide with education levels. As one resident put it "If you were uneducated, though, you got nothing.",170 The speaker goes on to imply the peasant reaction with "if it happened nowadays, it would be different, because our children read and write." $" 171$ Education became a "weapon of the weak" against a voracious modernity that fed on the peasantry. Overall resistance to modernity continued to characterize the peasant response to "development." In describing the damming of the Artibonite "each interviewee has

\footnotetext{
${ }^{109}$ Sidney Mintz, "Men Women and Trade," Comparative Studies in Society and History, v. 13, no. 3, July 1971. p. 257.

${ }_{171)}$ Paul Farmer, Aids and Accusation: Haiti and the Geography of Blame, p. 24.

${ }^{1\urcorner 1}$ Ibid.
} 
spoken of the unfairness of a project that destroys a way of life and offers benefits only to a faraway Port-au-Prince." 172 Because modernity often threatened the core of peasant society (family, land, and religion) it is no surprise that it was not readily accepted. Were Vodou and peasant proprietorship truly respected rather than trampled in the march of "progress," the situation would have been different.

172 Ibid., p. 26-27. 


\section{Dèyè Mòn, Gen Mòn}

The conflict between the state and the masses in their visions of modernity stretches back throughout Haitian history. The slave system that served as the foundation to the rise of modern western states was fueled by forced labor, maintained by oppression and justified through racism. In Haiti this system was destroyed and the question arose as to how it would enter into modernity. The masses were attached to the land and their insistence on maintaining these ties put them in direct opposition to the newly formed Haitian elite. These elite maintained a reverence for the very states that despised them and attempted to build Haiti according to positivist dictates. In attempting to reconcile with a world that remained hostile to an independent black republic the Haitian elite used the toil of the masses to pay an indemnity to France. This indemnity was directed at compensating former slave owners for their economic loss in exchange for recognition of Haitian independence. The result was a debilitating debt, which attracted imperial financiers who continued to build on the debt in an effort to assert themselves in a financially handicapped Haiti. The economic burdens of Haiti continued to fall upon the masses who were divorced from the power to confront them in the legislative sphere. Their circumscription was justified through institutional racism, which included a linguistic component.

The Haitian people were not complaisant in these events and their resistance earned them the derision of outside observers. When the masses exercised the power they did have, that of the machete or the 'Steamroller,' they were characterized as ignorant, backwards, savages. This detached posturing on the part of Western powers 
was based directly on an adherence to a racial hierarchy with whites at the apex and served as a justification for their continued interference in Haitian affairs. The most pronounced instance of racist intervention was the US occupation. The occupation served to cement both US hegemony and the position of the Haitian elite in opposition to the masses. Presidents Vincent and Lescot were glaring examples of the disjuncture between state and nation. The oppression intrinsic to these dictatorships catalyzed the "revolution of 1946" and the election of Estimé.

Though the position of most Haitians remained one of circumscription, they retained a certain respect for Estimé. In 1950 Estimé proposed legislation to alter the constitution and extend his term of office. The Senate voted against him. The Haitian public organized demonstrations in order to pressure the Senate to change their stance. With the public behind him, Estimé signed a decree to dissolve the Senate, but the military prevented its publication. The door was opened, and a coup instituted by a military junta forced Estimé to resign and seek exile in New York. ${ }^{173}$ Estimé died there three years later. ${ }^{174}$ Today in Haiti Dumarsais Estimé is remembered with more reverence and less revulsion than most Haitian Presidents. This is because of the hope his term in office presented. Noirisme had brought him to power and within it the general public perceived the antidote to the class antagonism that inundated the nation. If blacks and mulattos could unite under the name black then presumably they could be mutually uplifted. This possibility, which Estimé had made tangible again, would drive

\footnotetext{
${ }^{173}$ Memorandum by the Director of Middle American Affairs to the Assistant Secretary of State for Inter-American Affairs, FRUS: 1950, p. 933-34.

174 Abbott, Haiti: An Insider's History. p. 57.
} 
Haitian politics and result in the election of Francois Duvalier. For the United States the legacy of Estimé was that "racial complications" could pose a threat to hegemony. Therefore the class chasm was the key to relations with Haiti. A black president need no longer be feared provided they were amenable to U.S. interests. By no means did this represent a cleansing of U.S. racism in its relations with Haiti. It was simply a recognition that the noirisme of the 1940s was not going away and the United States needed to calculate that into their relations with Haiti.

In 1946 the reinvigorated noirisme of the occupation had emerged in the form of the Estime administration. The ultimate resonance of the Estimé presidency was that the Haitian government could not function in opposition to the peasantry. The U.S. could no longer rely upon the schism between black and mulatto to maintain hegemony. With this in mind the U.S. government sought to re-establish its hold on Haiti and deal with the "racial complications" of relations with the nation. SHADA was re-invigorated under the more favorable government of Paul Magloire, a black president sympathetic to U.S. interests. The U.S. began to focus on the peasantry through programs like the International Information and Education Exchange. This was a program in which American professors were sent to Haiti "for the purpose of teaching their specialties and imparting to Haitians information about the US."175 The program also entailed "an active press, radio and motion picture program in Haiti." It was a means of attempting to substitute U.S. education for the traditional French education, and more importantly for the African education stressed by the post-

\footnotetext{
${ }^{175}$ Policy Statement Prepared in the Department of State, FRUS: $195 /$, p. 1459.

${ }^{176}$ Ibid.
} 
occupation ethnology movement. It was also a means of directly addressing the increased agency of the Haitian people.

The Haitian population disliked Magloire's policies, which included repression of political dissidents and the press. In I956, Magloire was forced to resign and elections were held. The four primary candidates were Clement Jumelle, Daniel Fignolé, Loius Dejoie, and Francois "Papa Doc” Duvalier. Fignolé and Duvalier were both noiristes. Both had served under Estimé, and Duvalier, in particular, recognized Estimé's attractiveness to the Haitian public. Thus, Papa Doc appropriated the legend of Estimé in his campaign. Indeed, the noiristes considered Duvalier to be Estimé's successor. This became more pronounced when he enlisted the support of Estimé's widow, who accompanied him on his campaigns. His campaign was successful and in 1957 he was elected president. ${ }^{177}$

Under Estimé, noirisme had flourished and Haiti sought to re-assert itself as an independent black republic. In order to do so it had to combat U.S. hegemony, which had been firmly established since the occupation. The battle for greater Haitian autonomy was fought along lines of race and economics. When the United States refused aid to Haiti, the Estimé administration employed race. This tactic frequently worked because the U.S. refusal of aid to Haiti was often based on racism. The Estimé administration also played on U.S. fears of communist insurrection, as well as its own, to secure loans that were implemented under its own auspices. Estimé remained favorable to U.S. capital but refused to allow Americans to use loans as handcuffs. In

${ }^{177}$ Abbott, Haiti: An Insider's History. p. 64-5. 
order to reap a profit and secure his position of power, Estimé allowed for greater public expression of black culture, which had been repressed previous to him. All of this won him support from the Haitian public and opened the door for others such as Papa Doc to fight "under the banner of Estimisme."178

The significance of the Estimé presidency is partially a function of its timing. It was an answer to the occupation over ten years in the making. Vincent had proved himself to be an adherent of rather than an opponent to U.S. interests. He aligned himself in opposition to the people through his maintenance of a private guard and his weak response to the cane cutter massacre. Lescot was considered Vincent's successor and acted as such. The polarity between the elite and the masses could not continue in the same form and Estimé inherited the presidency from the people thereby breaking the mulatto dictatorships of the post-occupation period. Estimé proved himself to be more socially responsible than his predecessors and those who followed him. Yet it was in this web of interaction that power was contested. More particularly, it was within the rhetoric of noirisme as it related to modernity, that the dialogue of the United States Government, The Haitian elite, and the Haitian people took place.

Duvalier has not yet mutilated noirisme and its potency was very real. It was at once a recognition of popular agency in governance and a justification for elite domination. Under Estimé it was not yet clear to which end noirisme would ultimately be used. Hence, the U.S., the elite, and the masses battled for the power to define modernity. Modernity was linked to noirisme in that it was the end to which noirisme was posited as a means. The United States was put on the defensive as both its

\footnotetext{
${ }^{1-8}$ Nicholls, From Dessalines to Duvalier. p. 209.
} 
"whitening" corollary to modernity and its power to dictate Haitian governance were directly challenged. The elite attempted to appropriate blackness to fund urbanization as a catalyst to modernity. The masses attacked 'tiger cars' and protested in front of the SHADA building in opposition to a modernity that was more an affliction than a salve. 


\section{Bibliography}

\section{Primary Sources}

Manuscript Collections

Gainesville, Florida

Caribbean Collection, University of Florida Library

Frank Crumbie Papers, MS Group 14, Boxes 1,5, \& 6.

Newspapers and Periodicals

Cahiers d'Haïti

Le Matin

Le Nouvelliste

Pathinder

Saturday Evening Post

Government Documents

United States Department of State, Foreign Relations of the United States.

Washington, D.C.: Government Printing Office. 1914-1916, 1946-1951.

Published Works

Calixte, Demosthene Petrus. Haiti: The Cavalry of a Soldier. New York: Wendell Malliet, 1939.

Delafosse, Maurice. Les Noirs de 'Afrique. Paris: Payot, 1922.

Deniker, Joseph. Les Races et les peoples de la terre: elements d'anthropologie et d'ethnographie. Paris: Masson et cie, 1926.

Deschanel, Paul. Hommage de la jeunesse inellectuelle du Nord au president Dumarsais Estimé. Port-au-Prince: Impr de l'Etat, 1947. 
Hill, Robert, Ed. The Marcus Garvey and Universal Negro Improvement Association Papers. Los Angeles: University of California, 1983. Vol. I.

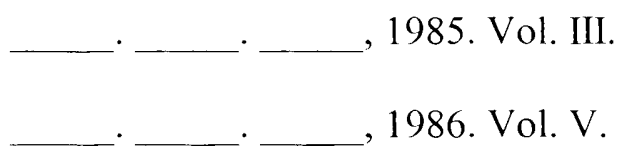

University of California Latin American Center. Statistical Abstract of Latin America. Los Angeles: University of California, 1965. Vol. IX. , 1966. Vol. X

\section{Secondary Sources}

Elizabeth Abbott. Haiti: An Insiders History of the Rise and Fall of the Duvaliers. New York: Simon and Schuster, 1991.

Baguidy, Joseph. Dynamique d'une revolution: 1946 a Haiti. Berne, Switzerland: Editions Coloroffset, 1972.

De La Fuente, Alejandro. A Nation for All: Race, Inequality, and Politics in TwentiethCentury Cuba. Chapel Hill, NC: University of North Carolina, 2001.

Deren, Maya. Divine Horsemen: Voodoo Gods of Haiti. New York: Chelsea House, 1970.

Dupuy, Alex. Haiti in the World Economy: Class, Race, and Underdevelopment Since 1700. Boulder, CO: Westview, 1989.

Estimé, Lucienne. Dumarsais Estimé: dialogue avec mes souvenirs. Port-au-Prince: Editions Memoire, 2001.

Farmer, Paul. Aids and Accusation: Haiti and the Geography of Blame. Berkeley: University of California, 1992.

Fergusson, James. A Traveller's History of the Caribbean. New York: Interlink Books, 1999.

Fick, Carolyn. The Making of Haiti: The Saint Domingue Revolution from Below. Knoxville, TN: University of Tennessee, 1990.

Francisque, Edouard. La structure economique et sociale d'Haiti. Port-au-Prince: Henri Deschamps, 1986. 
Gates, Henry Louis Jr. The Signifying Monkey: A Theory of Afro-American Literary Criticism. Oxford: Oxford University, 1988.

Heinl, Robert and Nancy. Written in Blood: The Story of the Haitian People 14921995. Lanham, MD: University Press of America, 1996.

Hoetink, Harold. "Race' and Color in the Caribbean," Caribbean Contours. Sidney Mintz and Sally Price, eds. Baltimore: Johns Hopkins University, 1985.

Hoffman, Leon-Francois. Haiti coulers croyances Creole. Port-au-Prince: Henri Deschamps, 1990.

Holt, Thomas. The Problem of Freedom: Race, Labor, and Politics in Jamaica and Britain, 1832-1938. Baltimore, MD: Johns Hopkins University, 1992.

James, Winston. Holding Aloft the Banner of Ethiopia: Caribbean Radicalism in Early Twentieth-Century America. London: Verso, 1998.

Franklin Knight. "The Haitian Revolution," American Historical Review 105, no. 1 (February 2000).

Lamartinière, Jacqueline. Le noirisme: essai sur la negritude et son utilisation dans le contexte haïtien. White Plains, NY: Mouvement haïtien de liberation, 1976.

Leyburn, James. The Haitian People. New Haven, CT: Yale, 1941.

Low'enthal, Ira. “'Marriage is 20, Children are 21:' the Cultural Construction of Conjugality and the Family in Rural Haiti." PhD Dissertation, Department of Anthropology, Baltimore: Johns Hopkins University, 1987.

Magloire, Jean. Pour defendre la memoire de l'illustrie president Dumarsais Estimé. Port-au-Prince: Impr. De l'Etat, 1957.

Mintz, Sidney. Caribbean Transformations. New York: Columbia University, 1989. . "Men, Women, and Trade," Comparative Studies in Society and History 13, no. 3 (July 1971).

Nicholls, David. From Dessalines to Duvalier: Race, Colour and National Independence in Haiti. New Brunswick, NJ: Rutgers University, 1996.

Pamphile, Leon. Haitians and African Americans: A Heritage of Tragedy and Hope. Gainsville, FL: University Press of Florida, 2001. 
Paquin, Lyonel. The Haitians: Class and Color Politics. New York: Multi-Type, 1983.

Plummer, Brenda Gayle. Haiti and the United States: The Psychological Moment. Athens, GA: University of Georgia, 1992.

Ramsey, Kate. "Without One Ritual Note: Folklore Performance and the Haitian State, 1935-1946," Radical History Review 84 (Fall 2002).

Renda, Mary. Taking Haiti: Military Occupation and the Culture of U.S. Imperialism, 1915-1940. Chapel Hill, NC: University of North Carolina, 2001.

Rey, Terry. Our Lady of Class Struggle: the Cult of the Virgin Mary in Haiti. Trenton, NJ: Africa World Press, 1999.

Schmidt, Hans. The United States Occupation of Haiti, 1915-1934. New Brunswick, NJ: Rutgers, 1971.

Scott, James. Domination and the Arts of Resistance: Hidden Transcripts. New Haven, CT: Yale, 1990. .Weapons of the Weak: Everyday Forms of Peasant Resistance. New Haven, CT: Yale, 1985.

Shannon, Magdaline. Jean Price-Mars, the Haitian Elite and the American Occupation, 1915-1935. New York: St. Martins, 1996.

Watkins-Owens, Irma. Blood Relations: Caribbean Immigrants and the Harlem Community, 1900-1930. Indianapolis, IN: Indiana University, 1996. 